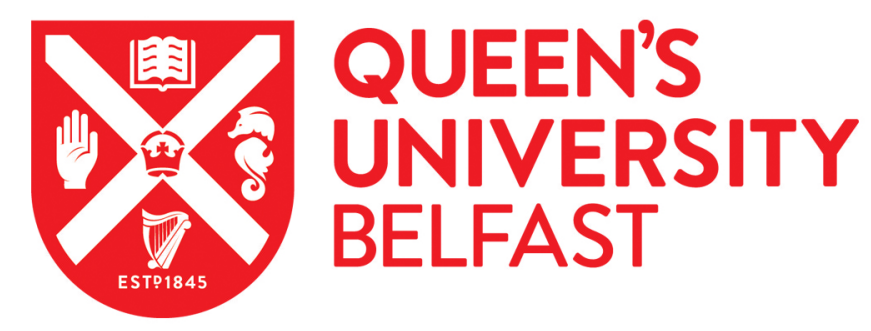

\title{
The Multiple Roles of the IAP Super-family in cancer
}

Kumar, S., Fairmichael, C., Longley, D. B., \& Turkington, R. C. (2020). The Multiple Roles of the IAP Superfamily in cancer. Pharmacology and Therapeutics, 214, 107610. [107610].

https://doi.org/10.1016/j.pharmthera.2020.107610, https://doi.org/10.1016/j.pharmthera.2020.107610

\section{Published in:}

Pharmacology and Therapeutics

\section{Document Version:}

Peer reviewed version

\section{Queen's University Belfast - Research Portal:}

Link to publication record in Queen's University Belfast Research Portal

\section{Publisher rights}

(c) 2020 Elsevier Inc. All rights reserved.

This manuscript version is made available under the CC-BY-NC-ND 4.0 license http://creativecommons.org/licenses/by-nc-nd/4.0/,which permits distribution and reproduction for non-commercial purposes, provided the author and source are cited.

\section{General rights}

Copyright for the publications made accessible via the Queen's University Belfast Research Portal is retained by the author(s) and / or other copyright owners and it is a condition of accessing these publications that users recognise and abide by the legal requirements associated with these rights.

Take down policy

The Research Portal is Queen's institutional repository that provides access to Queen's research output. Every effort has been made to ensure that content in the Research Portal does not infringe any person's rights, or applicable UK laws. If you discover content in the Research Portal that you believe breaches copyright or violates any law, please contact openaccess@qub.ac.uk. 


\section{The Multiple Roles of the IAP Super-family in Cancer}

Swati Kumar ${ }^{1}$, Ciaran Fairmichael ${ }^{1}$, Daniel B Longley ${ }^{1}$, Richard C Turkington ${ }^{1 *}$

${ }^{1}$ Centre for Cancer Research and Cell Biology, Queen's University of Belfast, Belfast, Northern Ireland.

*Corresponding author:

Dr Richard C Turkington

Centre for Cancer Research and Cell Biology, Queen's University Belfast, 97 Lisburn Road, Belfast, BT9 7AE, Northern Ireland, United Kingdom

Tel: +44 (0)289097 2756

Fax: $+44(0) 2890972776$

E mail: r.turkington@qub.ac.uk

This work is funded in part by:

Horizon 2020 Marie Sklodowska Curie Actions COFUND SPaRK programme, Movember Foundation.

Abstract Word Count: 89 words

Article Word Count: 9618 words

Number of Figures: 4 ; Number of Tables: 2 


\begin{abstract}
:
The Inhibitor of Apoptosis proteins (IAPs) are a family of proteins that are mainly known for their anti-apoptotic activity and ability to directly bind and inhibit caspases. Recent research has however revealed that they have extensive roles in governing numerous other cellular processes. IAPs are known to modulate ubiquitin (Ub)-dependent signaling pathways through their E3 ligase activity and influence activation of nuclear factor $\kappa B(N F \kappa B)$. In this review, we discuss the involvement of IAPs in individual hallmarks of cancer and the current status of therapies targeting these critical proteins.
\end{abstract}

Keywords: Inhibitors of apoptosis, hallmarks of cancer, cancer therapy, molecular targets 
Table of Contents:

1. Introduction

1.1.Discovery of the IAP family of proteins

1.2.Structure of the IAP family of proteins

1.3. Expression of IAP proteins in cancer and correlation to prognosis

2. Roles of IAP in cancer: Connecting to the hallmarks of cancer

2.1. Resisting cell death

2.2.Activating invasion and metastasis

2.3.Sustaining uncontrollable proliferation

2.4.Enabling Replicative Immortality

2.5. Angiogenesis

2.6.Reprogramming Energy Metabolism

2.7.Evading Immune Destruction

3. Targeting IAP proteins for cancer therapy

\subsection{SMAC mimetics}

3.2 Biomarkers for treatment response to SMAC mimetics

4. Conclusion 
Abbreviations:

BIR: Baculovirus IAP repeat

cIAP1: cellular inhibitor of apoptosis protein 1

clAP2: cellular inhibitor of apoptosis protein 2

CPC: Chromosomal passenger complex

DIABLO: Direct IAP binding protein with low pI

DFS: Disease-free survival

E2: Ubiquitin conjugating enzymes

ECM: Extracellular matrix

EMT: epithelial to mesenchymal transition

FAK: Focal adhesion kinase

HIF: Hypoxia inducible factors

hTERT: Human telomerase reverse transcriptase

IAP: Inhibitors of apoptosis

IBM: IAP-binding motif

IKK: IKB kinase

NAIP: Neuronal apoptosis inhibitor protein

NF kB: Nuclear factor kB

NIK: NFKB inducing kinase 
OS: Overall survival

PFS: Progression-free survival

RFS: Recurrence-free survival

RIPK1: Receptor-interacting serine/threonine-protein kinase 1

SMAC: Second Mitochondria-derived Activator of Caspases

TNFR: Tumor necrosis factor receptor

TNF $\alpha$ : Tumor necrosis factor $\alpha$

TRAF: Tumor Necrosis Factor Receptor Associated Factor 2

Ub: Ubiquitin

VEGF: Vascular endothelial growth factor

XIAP: X-Linked inhibitor of apoptosis protein 


\section{Introduction:}

The cells of multi-cellular organisms have the ability to activate an intrinsic cell suicide machinery associated with specific biochemical and morphological changes, termed apoptosis. This programmed cell death process is tightly regulated, and abnormalities in the apoptotic pathway have been associated with various human diseases such as cancer, neurodegeneration and autoimmune disease (Steller, 1995).

Inhibitor of Apoptosis Proteins (IAPs) are a family of proteins that regulate apoptosis by inhibiting caspases, which are cysteine-dependent aspartate-directed proteases that serve as the effector arm of this process. Initially, this was considered to be their primary function; however, recent studies have indicated that they have a number of different roles in other cellular processes. Various ubiquitin (Ub)dependent signaling events that regulate important transcription factors responsible for the expression of genes involved in cell migration, survival and inflammation are now known to be affected by various members of the IAP family (Gyrd-Hansen \& Meier, 2010). Moreover, many of these processes play roles in cancer initiation, metastasis and progression (Hunter, LaCasse, \& Korneluk, 2007; LaCasse, et al., 2008).

In this review, we discuss the broad range of functions of the IAPs in cancer development by assessing their roles in the various hallmarks of cancer. We also briefly discuss the most extensively studied means of targeting these proteins.

\subsection{Discovery of the IAP family of proteins:}

The first IAP genes identified were from the baculovirus Cydia pomonella granulosis virus (CpIAP) and Orgyia pseudosugata nuclear polyhedrosis virus (OpIAP) in a complementary assay looking to identify additional genes which had the potential to inhibit apoptosis in a line deficient in p35, a pan-caspase inhibitor. These genes were found to have no sequence homology to p35 but contained a zinc finger-like motif which is also found in other genes regulating apoptosis (Birnbaum, Clem, \& Miller, 1994; Crook, Clem, \& Miller, 1993). The first mammalian IAP to be discovered was the neuronal apoptosis inhibitor protein (NAIP). This was after several studies showing inhibition of apoptosis by the baculovirus IAP in 
various different species were published, raising the possibility of the protein having cellular homologs (Deveraux \& Reed, 1999; Verhagen, Coulson, \& Vaux, 2001). NAIP was identified during a positional cloning study that aimed to identify genes involved in spinal muscular atrophies (SMAs) as these disorders are characterized by the presence of swollen or chromatolysed motor neuron cells resembling the morphology of cells that have undergone programmed cell death or apoptosis (Duckett, et al., 1996; Roy, et al., 1995). Since the discovery of these IAPs, other members have been identified which include X-linked IAP (XIAP); identified in a search looking at sequences homologous to the baculovirus IAP protein CpIAP and in an effort to find other human genes encoding IAP-like proteins. The XIAP sequence was then used to find other homologous human IAP genes and resulted in the discovery of baculoviral IAP repeat containing 2 (BIRC2 or cellular IAP1 (CIAP1)) and baculoviral IAP repeat containing 3 (BIRC3 or cellular IAP2 (clAP2))(Listen, et al., 1996).

Tumor necrosis factor alpha (TNF $\alpha)$ is an inflammatory cytokine that mediates its effects through two distinct cell surface receptors, Tumor necrosis factor receptor 1 and 2 (TNFR1 and TNFR2). TNFR1 has been known to be involved in TNF $\alpha$-mediated apoptosis, with CIAP1 and CIAP2 purified and cloned as part of studies looking for proteins associated with these receptor complexes (Rothe, Pan, Henzel, Ayres, \& Goeddel, 1995). The human IAP family has subsequently expanded to include the following members: baculoviral IAP repeat containing 8 (BIRC8 or ILP-1/testis specific IAP (Ts-IAP)), which was discovered during the mapping and genomic characterization of XIAP as a testis-specific transcript (Lagacé, et al., 2001); Baculoviral IAP Repeat Containing 5 (BIRC5 or Survivin), which was identified by examining genes hybridizing to the effector cell protease receptor (EPR1) (Ambrosini, Adida, \& Altieri, 1997); and Baculoviral IAP Repeat Containing 6 (BIRC6 or BRUCE/Apollon) (Zhihong Chen, et al., 1999) and baculoviral IAP repeat containing 7 (BIRC7 or ML-IAP/Livin) (Kasof \& Gomes, 2001), both of which were identified through various homology searches. The IAP family of proteins now has 8 members comprising of NAIP, XIAP, cIAP1, cIAP2, Ts-IAP, Survivin, Apollon and Livin. 


\subsection{Structure of the IAP family of proteins:}

The defining structural feature of the IAP family of proteins is the baculovirus IAP repeat (BIR) domain. These BIRs are around 70 residues long and are zinc binding domains that facilitate protein-protein interactions. The eight mammalian IAPs contain one to three copies of this domain (Fig 1). BIRs possess certain common features which include the presence of three conserved cysteine residues and one histidine residue which coordinate a zinc ion that is required to stabilize the BIR fold (Srinivasula \& Ashwell, 2008). There are two types of BIR domain, type I and type II, and these are grouped on the basis of the presence of a deep peptide binding groove. The Type II BIRs contain a distinctive hydrophobic cleft through which they bind to specific N-terminal IAP binding motifs (IBMs) present on their interaction partners, caspases and IAP antagonists (Silke \& Meier, 2013; G. Wu, et al., 2000). The type I BIRs on the other hand do not have a deep peptide binding groove, but instead have a shallow pocket and so do not interact with caspases or IAP antagonists. They are, however, known to interact with different target proteins, with the type I BIR of XIAP having been reported to directly bind TAB1, an upstream adaptor of the Transforming Growth Factor- $\beta$ activated kinase 1 (TAK1) (M. Lu, et al., 2007), whereas the type I BIRs of cIAP1 and cIAP2 interact with Tumor Necrosis Factor Receptor Associated Factor 2 (TRAF2), which is an adaptor protein that facilitates signal transduction from the TNF receptor family (T. Samuel, et al., 2006). In addition to the BIR domains, IAPs also contain a carboxy-terminal RING finger domain (Fig 1). This domain enables IAPs to recruit ubiquitin conjugating enzymes (E2) through which ubiquitin can be transferred onto lysine residues of target proteins. Proteins are often poly-ubiquitinated, with addition of further ubiquitin moieties to lysine residues present in ubiquitin itself. Depending on the lysine residues to which the incoming ubiquitin is conjugated, poly-ubiquitinated chains with different topologies can be created that determine the fate of the target protein, with ubiquitin chains joined via lysine 48 (K48) residues of ubiquitin recognized by the proteasome and typically targeted for degradation (Vaux \& Silke, 2005). However, degradation is not the only outcome for poly-ubiquitinated proteins; for example, K63linked poly-ubiquitin chains can instead result in modification of biological activity or sub-cellular 
localization of the target protein (Komander \& Rape, 2012; Ni, Li, \& Zou, 2005). The RING domain of IAPs, such as CIAP1, have been shown to downregulate protein levels of other RING domain-bearing IAP family members by targeting them for degradation by both ubiquitin-dependent and -independent pathways (Cheung, Plenchette, Kern, Mahoney, \& Korneluk, 2008). With respect to ubiquitination, IAPs also contain a ubiquitin-associated domain (UBA) and a ubiquitin conjugating domain (UBC). Apollon is the only member of the human IAP family of proteins containing a UBC domain. This motif can function as ubiquitin conjugating enzyme (E2), allowing it to transfer ubiquitin to substrates directly (Bartke, Pohl, Pyrowolakis, \& Jentsch, 2004). XIAP, cIAP1, CIAP2 and Ts-IAP can bind to polyubiquitylated proteins and substrates through their UBA domains (Gyrd-Hansen, et al., 2008).

CIAP1 and CIAP2 also contain a caspase recruitment domain (CARD), a domain found in procaspase- 9 and APAF-1, which is important for formation of the caspase-9-activating Apoptosome (Li, et al., 2017). The exact function of the CARD in clAP1/2 is not fully elucidated, but it has been suggested that it plays a role in stabilizing the cIAP1 protein by inhibiting auto-ubiquitination by the RING domain (Oetjen \& Duckett, 2011). IAPs thus have structurally varied features that confer on them distinct functions by allowing them to interact with important proteins and thereby regulate important signaling pathways.

\subsection{Expression of IAP proteins in cancer and correlation with prognosis:}

Deregulation of IAPs at gene, mRNA and protein levels due to genetic aberrations, changes in mRNA or protein expression and loss of endogenous inhibitors, such as Second Mitochondria-derived Activator of Caspases (SMAC), have been reported in many different cancer types and correlated with treatment response and prognosis. Tamm et al. studied the expression of IAPs in a panel of 60 cancer cell lines from 9 different cancer types and found that most of the cell lines expressed XIAP and CIAP1; however, CIAP2 was not easily detected at the protein level in the majority of the cell lines. Notably, mRNA levels did not correlate with protein levels, suggesting posttranscriptional regulation is important for these proteins 
(Tamm, et al., 2000). Further exploration in clinical samples showed that IAPs were expressed in most cancer types, leading to more work being done to study their association with survival and response to therapy, as discussed below and summarized in Table 1.

Chromosomal aberrations in the 11q21-q23 regions which harbors the CIAP1 (BIRC2) and CIAP2 (BIRC3) genes have been reported in different cancer types. Imoto et al. found this region to be amplified in esophageal squamous cell carcinoma-derived cell lines and went on to identify the target for amplification at this region. They found that only cIAP1 was consistently over-amplified in the cell lines and also found it to be overexpressed in the primary tumors from which these cell lines were derived (Imoto, et al., 2001). Similar results identifying cIAP1 as the candidate proto-oncogene within this amplicon have been reported in pancreatic (Bashyam, et al., 2005), liver (Zender, et al., 2006), lung (Dai, et al., 2003) and other cancers. This includes cervical squamous cell carcinoma (CSCCs), in which amplification and overexpression of CIAP1 has been shown to be associated with resistance to radiation-induced cell death in cell lines, and it was also found to contribute to poorer overall survival (OS) and recurrence free survival (RFS) (Imoto, et al., 2002). In addition to $11 q$ chromosomal aberrations, the BIR domains of CIAP2 are also involved in the generation of an oncoprotein in mucosa-associated lymphoid tissue lymphoma which involves fusion of the N-terminus of clAP2 with mucosa-associated lymphoid tissue lymphoma translocation protein 1 (MALT1). This fusion protein constitutively activates the NF[B signaling pathway and is associated with advanced stage disease, particularly in cases of gastric MALT lymphomas, (Rosebeck, et al., 2011).

In acute myeloid leukemia (AML), a three gene expression signature which included clAP2 was identified that could predict overall survival in newly diagnosed patients (Hess, et al., 2007). However, there exists contradicting reports on the association of the IAP family member proteins with prognosis in AML (Tamm, et al., 2000; Tamm, et al., 2004 Carter, et al., 2003). Similar contradicting reports also exist for Survivin (Carter, et al., 2003; A. Pluta, et al., 2015) and therefore further studies are required in order to better understand the prognostic importance of the IAP family in AML. Expression/function of the IAP family proteins are also deregulated in other hematological malignancies (S Fulda, 2009). 
In renal cell carcinoma (RCC), higher XIAP expression levels were reported to be correlated with advancing tumor stage, dedifferentiation and grade of cancer. (Mizutani, et al., 2007; Ramp, et al., 2004). Notably, patients with bladder cancers expressing high levels of XIAP had significantly lower recurrence-free survival rates $(p$ value $=0.0015)$, and this could also independently predict recurrence of non-muscular invasive bladder cancer (HR: 3.46, 95\% Cl: 1.37-7.97, p value $=0.004)($ Ming, Tao, Yin, \& Na, 2007). Another study in bladder cancer looked at cIAP1/2 expression levels and found similar results (X. Che, et al., 2012). In addition to these findings, Chen et al. reported that RFS was significantly reduced in the patient group whose bladder cancers showed high expression and of CIAP1, 2 and XIAP (low IAP expression: mean RFS 39.2 months versus high IAP expression group: mean RFS 26.6 months, $p$ value = 0.001) (X. Chen, et al., 2013). They also found a positive correlation between nuclear clAP1 and Survivin expression, with high expression of both these IAPs correlating with shorter RFS times (low cIAP+ Sur: mean RFS 36.4 months versus high clAP+ sur: mean RFS 24.4 months, p value $=0.003)(\mathrm{X}$. Chen, et al., 2013).Furthermore, , a systematic review also showed that Survivin expression correlates with worse prognosis in bladder cancer (OS: pooled $\mathrm{HR}, 1.53 ; 95 \% \mathrm{Cl}, 1.02-2.29$ ) and (RFS: pooled $\mathrm{HR}, 1.81 ; 95 \% \mathrm{Cl}$, 1.30-2.52) and (PFS: pooled HR, 2.12; 95\% Cl, 1.60-2.82) (Jeon, Kim, Kwak, Kim, \& Ku, 2013).

Interestingly, in breast cancer, one study specifically reported that nuclear XIAP expression and not cytoplasmic expression correlated with shortened overall survival (Y. Zhang, et al., 2011). Another study showed that nuclear Survivin expression could independently predict outcome in terms of both relapsefree and overall survival (Kennedy, et al., 2003). Pluta et al. found that tumor XIAP and Survivin expression were associated with more advanced breast (P. Pluta, et al., 2015). Interestingly, in non-small cell lung cancer (NSCLC), patients with tumors expressing higher XIAP had longer overall survival as compared to patients with tumors expressing lower levels (60 months versus 24 months of median survival, $p$ value $=0.01$ ) (C. G. Ferreira, et al., 2001). In colorectal cancer (CRC), higher XIAP expression correlated with tumor differentiation, venous invasion and Dukes staging; moreover, XIAP expression was found to be an independent prognostic factor (HR: 2.730; 95\% Cl: 1.226-5.445; $p$ value $=0.0206$ ) (Xiang, Wen, Wang, 
Chen, \& Liu, 2009). High cIAP2 expression has also been associated with reduced survival rates in CRC (Krajewska, et al., 2005).

In pancreatic cancer (PC), upregulation of cIAP2 at the mRNA level correlated with resistance to various commonly used chemotherapeutic drugs cell line models (Lopes, Gangeswaran, McNeish, Wang, \& Lemoine, 2007). Another study showed that cIAP2 expression levels increase during the progression of PC and that co-expression of CIAP1 and 2 is a predictor of worse prognosis (Esposito, et al., 2007). In addition to CIAP1/2, the XIAP negative regulator XAF1 (XIAP-associated factor 1 ) has been shown to influence prognosis of PC patients, with low XAF1 levels correlating with shorter survival times (J. Huang, et al., 2010). Similar results have been published in hepatocellular carcinoma (Augello, et al., 2009) and gastric cancer (Shibata, et al., 2007). Recent systematic reviews conducted on studying the association between XIAP levels and cancer prognosis in patients with different cancers have suggested that increased XIAP levels correlate with unfavorable prognosis (Gao, et al., 2019; S. Li, et al., 2019)

These studies indicate that the most widely studied IAPs: CIAP1 and 2 and XIAP are frequently overexpressed in a number of cancers and that their levels could help predict prognosis and clinical outcomes.

\section{4 miRNA regulation of IAP expression}

miRNAs have been reported to influence important cellular processes in cancer and can function either as tumor suppressors or oncogenes by regulating gene expression. Several miRNAs are involved in different stages of the apoptotic process and are known to regulate components of both the extrinsic and intrinsic apoptotic pathway (Y. Peng \& Croce, 2016). Expression of various members of the IAP protein family are also reported to be affected by miRNAs, and this could be used to further develop the therapeutic targeting of these proteins in cancer. Xie $Y$ et al. have shown that miRNA-24 targets XIAP in cancer cells and its overexpression overcomes apoptotic resistance resulting in TNFa induced cell death (Xie, et al., 2013). Furthermore, in ovarian cancer tissues and cell lines, expression of miRNA-137 has been 
reported to correlate with XIAP expression and that expression of this miRNA resulted in increased sensitivity of ovarian cancer cells to cisplatin-induced apoptosis via its XIAP regulation activity (X. Li, et al., 2017). miRNA-200c and miRNA-212 have also been shown to downregulate XIAP in triple negative breast cancer (TNBC) (Ren, et al., 2014) and RCC (Gu, et al., 2017) respectively, resulting in reduced proliferation, migration and invasion of cancer cells. In RCC, miRNA-212 levels negatively correlated with XIAP and this also correlated with worse prognosis. Additionally, miRNA-based targeting of XIAP has been shown to regulate multi-drug resistance in retinoblastoma (Yang, Zhang, Lu, \& Wang, 2020). Similar studies have been published on miRNAs targeting survivin (Jingcao Huang, Lyu, Wang, \& Liu, 2015; Kogo, et al., 2015; C. Wang, Zheng, Shen, \& Shi, 2012) livin (Ye, et al., 2013) as well as clAP (Cao, et al., 2018), and this miRNA induced regulation of IAP expression plays an important role in controlling cancer cell proliferation, invasion and migration. 


\section{Roles of IAP in cancer: Connecting to the hallmarks of cancer:}

Since the discovery of the IAP family of proteins, various studies have shown that they play many diverse roles in addition to regulating apoptosis. In the next sections, we will provide an outline of their different roles, connecting them to the hallmarks of cancer. This emphasizes the importance of targeting the IAP family of proteins in cancer therapy as they directly or indirectly regulate various pathways involved in tumor growth and progression.

\section{1: Resisting cell death}

One of the hallmarks of cancer is the ability of tumor cells to evade cell death, and the role of IAPs in this evasion has been extensively studied. Cells undergo apoptotic cell death via two major pathways, the extrinsic and intrinsic pathways, and both ultimately result in the activation of caspases. The extrinsic pathway involves interactions of specific transmembrane receptors with their respective ligands and the TRAIL-R1/R2 (DR4/5)/TRAIL receptor/ligand pairs are the most extensively studied. Ligand binding triggers homotypic interactions between the cytoplasmic death domains (DDs) of these receptors and the DDs of the cytoplasmic adaptor protein FADD. Via its death effector domain (DED), FADD then assembles the death inducing signaling complex (DISC), into which procaspase- 8 is recruited and can be activated to initiate apoptotic signaling (Riley, Malik, Holohan, \& Longley, 2015). In the intrinsic apoptotic pathway, various intracellular stimuli cause changes in the permeability of the outer mitochondrial membrane, resulting in the release of pro-apoptotic proteins like cytochrome $c$ and SMAC. This then results in the activation of initiator caspase 9. Mitochondrial outer membrane permeabilisation (MOMP) is controlled by the members of the BCL2 family that include both pro- and anti-apoptotic proteins, such as $\mathrm{BCl}-2, \mathrm{BCl}-$ XL, Mcl-1 and A1, which are anti-apoptotic, and Bax, Bak, Bid, Bad, Bim, Noxa and Puma, which are the pro-apoptotic members (Wilson, Johnston, \& Longley, 2009). The two pathways converge as Bid is cleaved by caspase- 8 and result in activation of the effector caspases-3, -6 and -7 , which then go on to cleave specific target proteins that effect apoptosis (Elmore, 2007). 


\section{IAPs as direct inhibitors of caspases:}

The activity of both initiator and effector caspases are regulated by IAPs. The first studies on the mechanism of apoptosis inhibition by IAPs came in 1997 when Devereux et al. published reports where they found that XIAP can regulate caspase- 3 processing following caspase- 8 activation. Thus, it was shown that XIAP could inhibit the extrinsic apoptotic signaling pathway by targeting the downstream effector caspases, as opposed to directly affecting caspase-8 activity. On the other hand, IAPs were also shown to inhibit the initiator caspase-9 in the intrinsic apoptotic pathway, thereby regulating the proteolytic activation of procaspases-3 and -7 (Deveraux, et al., 1998; Deveraux, Takahashi, Salvesen, \& Reed, 1997). Thus, XIAP can control both initiator caspase- 9 and effector caspases-3 and -7 activities directly in order to regulate the extrinsic and intrinsic apoptotic pathways.

XIAP interacts with caspase-9 through its BIR3 domain, with its C-terminus binding to the dimer interface of caspase-9. This prevents the conformational changes needed for the generation of the active catalytic pocket, thereby inhibiting its activity (Berthelet \& Dubrez, 2013). In the case of the interaction of XIAP with caspases-3/7, the residues in the linker region between BIR1 and BIR2 are involved and bind to the active site pocket of the caspases. The BIR2 domain of XIAP makes additional contacts with an IBM motif on the effector caspases thereby enhancing XIAP's interaction with the caspase (Riedl, et al., 2001; C. Sun, et al., 1999). The role of the RING domain in inhibiting caspases has been studied in mouse models. Schile et al. created a mouse model with a truncated RING domain and observed that cells expressing the RING mutant had significantly higher caspase activity and were sensitized to TNFa-induced apoptosis, indicating that the BIR domain alone is not enough to inhibit caspases (Schile, Garcia-Fernandez, \& Steller, 2008).

CIAP1 and 2 have been reported to bind to caspases, but do not have the ability to directly inhibit them, making XIAP the only member to act as a direct inhibitor of caspases (Eckelman \& Salvesen, 2006; Eckelman, Salvesen, \& Scott, 2006). 


\section{Role of IAPs in regulating cell survival and inflammation via NFKB signaling pathway:}

In addition to directly inhibiting caspases, IAPs play a very important role in regulating the NFKB signaling pathway, which regulates expression of many different target genes that promote cell proliferation as well as regulate apoptosis, invasion and metastasis (Park \& Hong, 2016; Xia, et al., 2018). NFkB is a family of hetero- and homo-dimeric transcription factors that consists of the components RELA, RELB and CREL along with the precursor ankyrin containing proteins NFkB1 (p105) and NFkB2 (p100). The latter are processed via the proteasome to generate $\mathrm{p} 50$ and $\mathrm{p} 52$ respectively. p50/52 do not contain any transactivating domains and therefore depend on their interaction with RELA, RELB and CREL to drive transcription. There are different ways in which NFkB can be activated, classified into two distinct pathways: canonical or non-canonical pathway, both of which are regulated by ubiquitination-dependent signaling cascades (J. Chen \& Chen, 2013; Perkins, 2007).

Canonical NFkB pathway: The most studied mechanism of activation of the NFKB pathway is via binding of TNF $\alpha$ to its receptor TNFR1, resulting in the recruitment of TRADD, TRAF5, TRAF2, cIAP1, cIAP2 and Receptor-interacting serine/threonine-protein kinase 1 (RIPK1) to form "Complex-I". cIAP, through its E3 ligase activity, then conjugates components of this complex with ubiquitin. One of the components that is Ub conjugated by cIAP is RIPK1 (Bertrand, et al., 2008), which then recruits the Linear UB chain assembly complex (LUBAC) that is composed of HOIL/HOIP/Sharpin, the kinases TAK1/TAB2/TAB3 and the IKB kinase (IKK) complex composed of IKK $\alpha /$ IKK $\beta / N E M O$. LUBAC then adds Ub chains to NEMO which undergoes a conformational change resulting in the autophosphorylation of IKK. Activated IKK then phosphorylates inhibitor of $\mathrm{\kappa B}(\mathrm{I} \mathrm{KB})$ which undergoes Ub-dependent proteasomal degradation allowing NFKB to translocate to the nucleus leading to the expression of its target genes (Behrends \& Harper, 2011; Darding \& Meier, 2012). In the absence of cIAPs, TNFR1 stimulation leads to the formation of a different complex that is mainly composed of RIPK1, FADD and caspase-8 called Complex-IIB. This complex is similar to the DISC and can activate caspase-8, leading to apoptosis (Petersen, et al., 2007; Vince, et al., 2007). Breakdown of Complex-I following de-ubiquitination of RIPK1 by the de-ubiquitinating enzymes (DUBs) 
Cylindromatosis (CYLD), Cezanne and A20 results in the formation of a secondary complex termed Complex-IIA, which consists of TRADD instead of RIPK1, FADD and caspase-8. Complex-IIA, Complex-IIB and the DISC also contain the caspase-8 paralog and regulator c-FLIP (cellular Fas-associated death domain (FADD)-like interleukin-1 $\beta$-converting enzyme (FLICE/caspase-8)-inhibitory protein). Depending on its expression levels, FLIP can inhibit caspase-8 activation in these complexes, thereby promoting cell survival. As the FLIP gene (CFLAR) is an NFKB target, Complex-I can modulate the signaling outcomes from Complex-IIA/B. This includes a non-apoptotic form of cell death termed necroptosis, which is mediated by RIPK1 and RIPK3 (Tsuchiya, Nakabayashi, \& Nakano, 2015). The long splice form of FLIP, FLIP(L), and caspase-8 can form an enzymatically active heterodimer in Complex-IIA/B, which cleaves RIPK1, thereby preventing the induction of necroptosis, a much more pro-inflammatory form of cell death than apoptosis (Humphreys, Espona-Fiedler, \& Longley, 2018; Micheau \& Tschopp, 2003; L. Wang, Du, \& Wang, 2008). The ripoptosome is another complex with the same composition as Complex-IIB but formed in the absence of TNFR1 stimulation, which is induced in response to clAP1/2 depletion following high dose chemotherapy or treatment with IAP antagonists (Imre, Larisch, \& Rajalingam, 2011; Tenev, et al., 2011). (Fig 2a)

Thus, IAPs play a pivotal part in death receptor signaling pathways through their role in ubiquitination of components of complex I leading to recruitment of LUBAC and subsequent activation of NFKB and also by negatively regulating the formation of the RIPK1-dependent ripoptosome complex which can promote cell death via apoptosis and necroptosis.

Non-canonical NFKB signaling pathway: Non-canonical NFKB activation occurs mostly in response to stimulation by TNF family receptors such as CD4OL, B cell activating factor (BAFF) and TWEAK. It depends on the proteasomal processing of NFKB2 to its $\mathrm{p} 52$ form which is regulated by NFKB-inducing kinase (NIK) (S. C. Sun, 2011, 2017). In resting cells, NIK is constitutively degraded through the formation of a Ub ligase- 
dependent complex that consists of TRAF3-TRAF2 and cIAP1 and/or 2. TRAF3 directly binds NIK, but studies have shown that the cIAP-mediated Ub ligase activity is needed for the conjugation of degradative polyubiquitinated chains linked to NIK (Zarnegar, et al., 2008). Ligand binding to CD40L/BAFF/TWEAK results in TRAF3 being targeted for proteasomal degradation following ubiquitination by cIAP. In the absence of TRAF3, NIK can no longer be recruited to the cIAP/TRAF complex, therefore its levels increase. Stabilized NIK phosphorylates IKK 3 , which in turn phosphorylates p100/NFKB2 triggering the latter's proteasomal processing to $\mathrm{p} 52$. Processed p52 complexes with RelB and stimulates expression of the heterodimer's (Fig 2b). Thus, in contrast to their role in the canonical NFkB pathway, IAPs negatively regulate the non-canonical NFKB pathway by preventing the accumulation of NIK.

\section{Role of IAPs in regulating autophagy:}

Autophagy is an important catabolic process that normally functions at low basal levels, but can be induced in response to stressful conditions, with the most common being nutrient deficiency. It functions by the formation of autophagosomes that capture degraded cellular components and fuse with lysozomes to recycle them. Autophagy is a double-edged sword as it is a tumor suppressive process, but can promote therapy resistance by enabling tumor cells to survive chemotherapy-induced stress (Das, Shravage, \& Baehrecke, 2012; Yun \& Lee, 2018). Recent evidence points to the role of IAPs in regulating autophagy, with XIAP, CIAP2 and BRUCE reported to play a role in regulating autophagosome and lysozome fusion (Ebner, et al., 2018; Gradzka, et al., 2018; Pötsch, et al., 2018). In addition, XIAP and cIAP1 induce autophagy by upregulating the expression of Beclin-1, which is an important modulator of autophagy. The resistance to chemotherapy observed in cancers overexpressing XIAP and CIAP1 has been related, at least in part, to induction of autophagy caused by Beclin-1 upregulation (Lin, et al., 2015).

In contrast to these reports suggesting a positive role of IAPs in mediating autophagy, IAPs are also known to inhibit autophagy. Che et al. reported that loss of BRUCE induces autophagy and 
increases autophagic activity by lowering cellular energy levels (L. Che, et al., 2019). XIAP has also been shown to inhibit autophagy via its ubiquitin E3 ligase activity by interacting with MDM2, which is a negative regulator of the proto-oncoprotein p53 (X. Huang, Wu, Mei, \& Wu, 2013). It appears therefore that IAPs can inhibit or induce autophagy depending on the specific IAP and cellular context.

\section{IAPs and cancer stem cells:}

Dysregulation of various signaling pathways play an important role in resistance to cell death in cancer stem cells (CSCs). These CSCs are believed to be one of the main reasons for recurrence in many different cancer types and this is due to their treatment-resistant nature. The IAP family of proteins have been implicated in contributing to the resistance mechanisms seen in CSCs (A. R. Safa, 2016; Ahmad R Safa, 2019). Survivin is one of the most studied IAP family member in this context. Yu et al. have reported that breast cancer stem cells show elevated expression of survivin, and this was associated with multi-drug resistance and reduced apoptosis ( $\mathrm{Yu}, \mathrm{Ou}$, Wang, Jialielihan, \& Liu, 2015). Survivin expression is also reported to play a role in 5FU resistance in CD133+ colon cancer stem cells (M.-R. Lee, Ji, Mia-Jan, \& Cho, 2015). Another study looking to identify therapeutic targets to overcome chemoresistance in colon cancer stem cells identified BRUCE as a target using a proteomics approach. They found that BRUCE was one of the top upregulated proteins in the stem cell population as compared to the differentiated cells (Van Houdt, et al., 2011). Interestingly, Siddarth et al. report the presence of a population of quiescent-breast cancer stem cells in a cell line model of metastasis. This population of adherent, pre-metastatic stem cells were found to express survivin which was important in the epithelial to mesenchymal transition of the cells and favored invasion and metastasis (Siddharth, Das, Nayak, \& Kundu, 2016). Also, Tchoghandjian et al. showed that targeting IAP proteins with their 
respective antagonists, resulted in loss of stemness and differentiation of glioblastoma cancer stem-like cells which was via regulation of the NFkB pathway. They also went on to show that targeting IAPs under hypoxic conditions resulted in loss of cell viability of the gliobasltoma stemlike cells, reduced proliferation and increased apoptosis but did not affect stemness (Souberan, et al., 2019; Tchoghandjian, et al., 2014). This is particularly important as hypoxia is one of the many reasons for chemoresistance seen in cancer cells, and the fact that cancer stem cells in hypoxic regions could be targeted by IAP antagonists makes them clinically relevant targets. Further research is required to investigate the potential of targeting IAPs in cancer stem cells.

\subsection{Activating Invasion \& Metastasis}

One of the striking features of cancer cells is their ability to migrate from the primary site of tumor formation to distant sites through a process of invasion and metastasis. During tumorigenesis, cancer cells develop ability to alter their shape as well as their interactions with other cells and the extracellular matrix (ECM). This is now thought to involve an epithelial to mesenchymal transition (EMT) which results in increased expression of mesenchymal markers, such as $\mathrm{N}$-cadherin, vimentin and fibronectin, that help invasion of surrounding tissues, a necessary first step of metastasis (Hanahan \& Weinberg, 2011; Martin, Ye, Sanders, Lane, \& Jiang, 2013). The IAP family of proteins have now been shown to be involved in various stages of cell migration, invasion and metastasis and this will be discussed further in the section below and is summarized in Fig 3.

\section{Role of IAPs in regulating cell adhesion molecules:}

Recent studies have highlighted the role of IAPs in the induction of the EMT process, with Jo et al. showing that cIAP2 promotes migration and invasion of TNBC cells by inducing EMT via activation of the AKT signaling pathway. They showed that silencing of clAP2 resulted in reduced levels of mesenchymal 
markers at both protein and mRNA level and also reduced the ability of breast cancer cells to migrate and invade the matrigel in wound-healing assays (Jo, et al., 2017). Similar results were found for Livin in promoting EMT in breast cancer cells in vitro by enhancing cell motility, invasiveness and metastasis (F. Li, et al., 2013). In addition to CIAP and Livin, XIAP and Survivin also reportedly play some role in the EMT process. Yi X et al. showed that simultaneous silencing of XIAP and Survivin in pancreatic cancer cells resulted in partial reversion of EMT, with increased expression of epithelial markers like E-cadherin and down-regulation of mesenchymal markers like Slug (Yi, Han, Li, Long, \& Li, 2015). Survivin is also said to play a role in activating the EMT induced by insulin-like growth factor (IGF) in hepatocellular carcinoma (HCC) (F. Liu, et al., 2018).

Integrins are membrane receptors that link ECM components such as fibronectin and vitronectin to the actin cytoskeleton and various focal adhesion molecules, including Src and focal adhesion kinase (FAK). These molecules are responsible for regulating signals controlling cell adhesion, migration, survival and proliferation through phosphorylation of adherens junction components (Dubrez \& Rajalingam, 2015). Recently, it has been reported that XIAP can interact with caveolin-1 and that this interaction is essential for endothelial cell survival (Kim, et al., 2008). Caveolin-1 is an integral membrane protein that regulates integrin-mediated cell adhesion. The authors have also shown that through its interaction with Caveolin$1, \mathrm{XIAP}$ is recruited to the focal adhesion complex. This facilitates the joining of the integrin complex to the kinase FAK, which then results in FAK-mediated activation of ERK1/2, ultimately leading to increased endothelial cell survival and migration (Figure 3A) (Kim, et al., 2010). It has now been shown that XIAP regulates FAK activity by controlling FAK phosphorylation and that XIAP knockdown in endothelial cells resulted in decreased recruitment of FAK to the focal adhesion site, thereby affecting its interaction with Src. This in turn disrupted the activation of ERK1/2, thus inhibiting cell adhesion and migration (Ahn \& Park, 2010). Since both Src and FAK play an important role in regulating the stability and availability of Ecadherin (Avizienyte \& Frame, 2005; Pei, Lan, Chen, Ji, \& Hua, 2017), XIAP-mediated regulation of FAK activity could also play a major role in epithelial cell migration and participate in the process of cancer cell 
invasion and metastasis. Additionally, Mehrotra et al. demonstrated that XIAP in a complex with Survivin promotes invasiveness in breast carcinoma cells and is also responsible for metastatic dissemination in vivo. This XIAP/Survivin complex was shown to upregulate NFKB-mediated transcription of fibronectin, resulting in the activation of $\beta$-integrins via autocrine/paracrine signaling which led to the phosphorylation and activation of cell motility kinases Src and FAK (Mehrotra, et al., 2010).

IAPs also appear to interact with various migration-associated pathways like ERK/MAPK, TGF $\beta$ and, as discussed earlier, NFKB. cRAF is a central member of the MAPK pathway, the increased activation of which activates ERK1/2, an important regulator of cell motility (Figure 3B). XIAP, cIAP1/2 and even ML-IAP have been shown to directly interact with cRAF. Dogan et al. have shown that both XIAP and clAP1/2 directly bind to CRAF and that silencing of XIAP and cIAPs leads to stabilization of CRAF and increased cell migration (Dogan, et al., 2008). Similar findings have been published by Oberoi-Khanuja et al., who reported a direct interaction between ML-IAP and CRAF. This binding results in CRAF being targeted for proteasomal degradation, with loss of ML-IAP resulting in increased MAPK activation and cell migration (OberoiKhanuja, Karreman, Larisch, Rapp, \& Rajalingam, 2012).

In addition to CRAF and ERK/MAPK signaling, IAPS also modulate gene expression induced in response to TGF $\beta$, which regulates transcription of various EMT regulators and also controls actin cytoskeleton and fibronectin expression (Hao, Baker, \& Ten Dijke, 2019). XIAP has been reported to act as a cofactor in TGF $\beta$ signaling independent of its role in apoptosis by associating with members of the type I class of TGF $\beta$ receptors (Birkey Reffey, Wurthner, Parks, Roberts, \& Duckett, 2001). Also, in esophageal carcinoma cell lines, XIAP has been reported to enhance cell migration by activating TGF $\beta$, which then promotes EMT (Jin, Lu, Wang, Zhao, \& Xue, 2019). As discussed previously, IAPs are now well-known regulators of the canonical and non-canonical NFאB signaling, which is also known to play an important role in cancer cell migration/invasion by regulating Snail and other EMT regulators (Y. Wu \& Zhou, 2010). 


\section{Role of IAPs in regulating RhoGTPases:}

Tumor invasion and metastasis involves the remodeling of the actin cytoskeleton resulting in changes in cellular organization and in cell adhesion with the surrounding tissues. It involves extension of membrane protrusions in the cell front to enable interaction with the ECM and focal adhesion complexes. RhoGTPases are a family of proteins that are known to play an important role in regulation of cell shape and remodeling of the actin cytoskeleton during cell migration. RhoA, Rac and Cdc42 are the most studied members of this family of proteins (Haga \& Ridley, 2016). Interaction of IAPs with RhoGTPases has been confirmed by various studies (Figure 3C). Oberoi et al. demonstrated that both XIAP and cIAP directly bind to the RhoGTPase member Rac1, resulting in its ubiquitination and proteasomal degradation; moreover, they found that downregulation of IAPs restores Rac1 levels, leading to enhanced cell migration and changes in cell morphology (Oberoi-Khanuja \& Rajalingam, 2012; Oberoi, et al., 2012). RhoGDI regulates GDP-GTP nucleotide exchange and promotes actin cytoskeleton reorganization in fibroblast cells. Marivin et al. reported that cIAP1 directly interacts with $\mathrm{Cdc} 42$ and promotes its stabilization following TNF $\alpha$ stimulation (Marivin, et al., 2014). XIAP has also been shown to interact with RhoGDI and regulate cytoskeleton formation leading to increased cell motility (J. Liu, et al., 2011); subsequently, XIAP knockdown resulted in a reduction of $\beta$-actin polymerization, which was associated with decreased cell migration and invasion. This role of XIAP in regulating the cell motility is independent of its caspase regulatory activity but required the XIAP RING domain, although this was not found to be directly involved in interaction with RhoGDPI (J. Liu, et al., 2012). These studies show that IAPs are regulators of RhoGTPases and thereby play an important role in the cell migratory process.

\subsection{Sustained proliferation:}

Normal cells have a carefully regulated process of the release and production of growth factors that control the entry into and advancement through the various stages of the cell cycle. This ensures that 
homeostasis is achieved and cell numbers are maintained at normal levels. Cancer cells are known to deregulate these signals, thereby becoming resistant to proliferation control mechanisms and acquire the ability to sustain chronic proliferation (Hanahan \& Weinberg, 2011). They achieve this property by altering expression of various cell cycle proteins, constitutive activation of various signaling pathways and by interfering with the regulation and production of various growth factors (Feitelson, et al., 2015).

One of the most striking ways in which IAPs contribute to this sustained proliferation seen in cancerous cells is by being involved in the cell cycle process and Survivin the most studied IAP in this context. Survivin is reported to be a nuclear-cytoplasmic shuttling protein with a different role in each region. It contains a nuclear export sequence that enables this movement, with the cytoplasmic protein playing a role in suppressing apoptosis, as discussed earlier, while nuclear Survivin is reported to regulate proliferation (Colnaghi, Connell, Barrett, \& Wheatley, 2006; Connell, Colnaghi, \& Wheatley, 2008). The role of Survivin in cancer cell proliferation stems from its cell cycle specific regulation, and it is localized at different regions of the chromosome during the cell cycle (Altieri, 2004). Additionally, Survivin also forms an integral part of the chromosomal passenger complex (CPC). The CPC functions to ensure that the chromosomes are segregated properly during cytokinesis and is also responsible for establishing an orderly exit from mitosis. This is critical because dysfunctional mitotic exit or a defect in chromosome segregation can lead to genomic instability (Kitagawa \& Lee, 2015; Ruchaud, Carmena, \& Earnshaw, 2007b). The CPC is composed of 4 proteins with aurora B kinase being the enzymatic subunit and Survivin, inner centromere protein (INCEP) and borealin acting as its regulatory subunits. They all have interconnected roles and if either of them is dysfunctional, the others fail to localize and aurora B kinase does not function properly. Survivin is reported to serve as an interface between the centromere and the CPC and also mediates colocalization of the CPC to its specific mitotic structures (Ruchaud, Carmena, \& Earnshaw, 2007a; Vader, Kauw, Medema, \& Lens, 2006). Aurora kinases are also known to interact with the tumor suppressor protein p53 and phosphorylate it, leading to accelerated proteasomal degradation. Although, their 
interactions with mutant p53 need to be studied further, the CPC definitely plays an important role in regulating cell proliferation (Gully, et al., 2012; Sasai, Treekitkarnmongkol, Kai, Katayama, \& Sen, 2016).

In addition to be being a part of the CPC, Survivin has also been reported to be involved with other cell cycle regulators. It is phosphorylated by cyclin dependent kinase-1 (CDK1), and this increases the affinity of Survivin for caspase-9 during cell division which could prevent apoptosis of dividing cancerous cells (Chandele, Prasad, Jagtap, Shukla, \& Shastry, 2004; O'Connor, Grossman, et al., 2000; O'Connor, Schechner, et al., 2000). Cyclin dependent kinases (CDKs) are the key regulators of cell cycle progression and are controlled by several different processes. This involves binding of activating cyclin subunits and

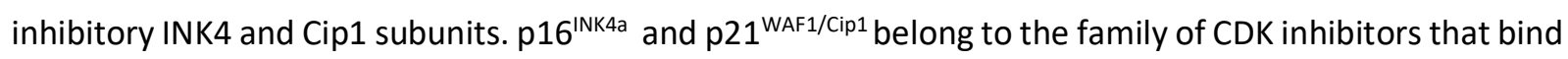
to $\mathrm{CDK} 4 /$ cyclin D1 and CDK2/cyclin E complexes and inhibit their activation and thereby play important role in G1 arrest (Satyanarayana \& Kaldis, 2009; Sherr, Beach, \& Shapiro, 2016). Suzuki et al. have also shown that overexpression of Survivin results in an accelerated shift to the $S$ phase, accompanied by increased resistance to $\mathrm{G} 1$ arrest. This is via its interaction with the $\mathrm{CDK} 4 / \mathrm{p} 16^{\mathrm{INK} 4 \mathrm{a}}$ complex resulting in activation of CDK2/cyclin and phosphorylation of the retinoblastoma ( $\mathrm{Rb}$ ) protein. Rb phosphorylation is important in transversal through G1 and entry into the S phase of the cell cycle and results in inactivation of its proliferation suppressive function (Suzuki, et al., 2000). Similar results were shown by lto et al. in HCC cell lines, with Survivin overexpression resulting in obliteration of the G1 checkpoint mediated by Survivin induced release of p21WAF1/Cip1 from CDK4 (Ito, et al., 2000). The fact that Survivin interacts with these complexes suggests that it could play an important role in sustaining cell proliferation seen in cancer cells.

The other members of the IAP family, cIAP1 and Livin have also been reported to play a role in cell cycle regulation. cIAP1 is now known to localize to the nucleus and modulate the cell cycle, with its overexpression associated with genomic defects and cell cycle aberration (Temesgen Samuel, et al., 2005). cIAP1 also plays a role in regulating E2F1 transcriptional activity when localized in the nucleus. E2F1 is a member of an important family of transcription factors that regulate cell differentiation and proliferation 
resulting in expression of genes that are essential in cell cycle progression. The E3 ligase activity of clAP1 aids in polyubiquitination of lysine residues that are associated with E2F1 transcriptional stability and activity (Cartier, et al., 2011; Glorian, et al., 2017). Livin is also reported to be involved in regulation of cell proliferation and transition to various stages of the cell cycle. Silencing of Livin results in inhibition of cell proliferation and cell cycle arrest at G0/G1 phase (LinLin Wang, Zheng, Tang, Li, \& An, 2009; R. Wang, et al., 2008; Ye, et al., 2011) .

Cell proliferation is regulated by various molecular pathways whose constitutive activation results in uncontrollable tumor growth and division. Expression of various members of the IAP family are modulated by interacting with prominent cell signaling pathways. For example, Survivin is known to be critically modulated by interacting with heat-shock protein (hsp90), which is a chaperone protein responsible for maintaining the integrity of the cellular protein network; moreover, this interaction is known to promote tumor proliferation (Fortugno, et al., 2003; Kanwar, Kamalapuram, \& Kanwar, 2011). Myc is an oncogene that is dysregulated in many cancers and has a central role in many aspects of the oncogenic process including cell proliferation. Xu et al. have demonstrated that cIAP1 is responsible for ubiquitination of the Myc repressor Mad1 leading to its proteasomal degradation. This reduction in Mad1 levels then resulted in Myc-mediated promotion of cell proliferation and transformation (L. Xu, et al., 2007).

Taken together, these studies show that IAPs can regulate tumor cell proliferation at different levels.

\section{4: Enabling Replicative Immortality}

In contrast to normal cells that undergo a finite number of cell division cycles before entering senescence or undergoing apoptosis, cancer cells acquire the ability to undergo unlimited proliferation; this is associated with aberrant expression of hTERT (human telomerase reverse transcriptase). hTERT maintains telomeres and prevents telomere shortening, which normally happens during each cell division, from triggering senescence/apoptosis. A number of reports 
have correlated Survivin expression with hTERT expression in tumor tissues (KleinschmidtDeMasters, et al., 2003; Lam, Saleh, Smith, \& Ho, 2008; Wellenhofer \& Brustmann, 2012; Würl, et al., 2002). Moreover, recent reports have shown that Survivin also regulates telomerase activity. Endoh et al. demonstrated that overexpression of Survivin enhanced hTERT expression in colon cancer cells. They then went on to show that Survivin increases hTERT expression by increasing the binding of specificity protein-1 (Sp1) and c-Myc to the hTERT promoter via phosphorylation of these transcription factors and this ultimately results in increased hTERT gene transcription (Endoh, Tsuji, Asanuma, Yagihashi, \& Watanabe, 2005). Further research into this mechanism showed that Survivin phosphorylates Sp1 and c-MYC via its interaction with aurora B kinase (Furuya, Tsuji, Kobayashi, \& Watanabe, 2009). Also, Yuan et al. reported that in nontransformed human fibroblasts transduced with hTERT, Survivin expression dramatically increased during immortalization, and this resulted in the cells being resistant to apoptosis (Yuan, et al., 2009). Moreover, they reported that expression of hTERT alone is not sufficient to induce immortalization and that increased expression of Survivin is also required.

\subsection{Angiogenesis}

Angiogenesis involves formation of new blood vessels from pre-existing ones, and vasculogenesis involves the generation of new endothelial cells which then go on to assemble into new blood vessels. Tumor cells are unable to grown in size, invade surrounding tissues and sustain growth if they fail to activate this process, which is one of the classical hallmarks of cancer (Yadav, Puri, Rastogi, Satpute, \& Sharma, 2015). Various studies have shown that Survivin expression correlates with angiogenesis in different cancers (Kawasaki, et al., 2001; G.-H. Lee, et al., 2006; J. Li \& Wu, 2006; Zhen, et al., 2005). In addition, co-expression of Survivin with the pro-angiogenic 
factor VEGF correlated with cancer metastasis, stage and also prognosis in small-cell lung (P. Chen, et al., 2014), nasopharyngeal carcinoma (Y. H. Li, et al., 2008) and thyroid cancer (H. Y. Zhang, et al., 2009) and was also associated with tumor relapse in superficial bladder transitional cell carcinoma (Y. W. Sun, et al., 2013).

Two decades ago, it was reported that VEGF induces Survivin expression in vascular endothelial cells in a cell cycle dependent manner and that this facilitated angiogenesis (Tran, et al., 1999). Similar findings were also reported by Connor et al., where they show that formation of threedimensional vascular tubes in vitro in endothelial cells was associated with a marked induction of Survivin by VEGF. Also, in vivo studies have shown that Survivin was minimally expressed in the endothelium of normal skin, but was significantly upregulated during angiogenesis in newly formed blood vessels in granulation tissue (O'Connor, Schechner, et al., 2000). Meng et al. demonstrated that VEGFR signaling upregulated Survivin expression via the AKT/MDM2 pathway and that this was essential for tumor cell survival (Meng, et al., 2018). It has also been shown in glioma cells that Survivin can promote endothelial cell migration and proliferation and also increase microvessel density (a surrogate marker for tumor angiogenesis); moreover, this was attributed to Survivin-induced expression of angiogenic factors VEGF and FGF (P. Wang, et al., 2012). These findings are further supported by Li et al., who found that in rat aortic endothelial cells, Survivin promoted tumor angiogenesis via enhanced tube and microvessel formation, which was accompanied by increased expression of VEGF (Z. Li, et al., 2016).

Studies in zebrafish have shown that Survivin knockdown greatly impairs the process of angiogenesis in embryos and leads to developmental defects; notably, VEGF was able to entirely rescue this phenotype (Delvaeye, et al., 2009; Ma, et al., 2007). Moreover, in neuroblastoma cells, Survivin knockdown combined with flavonoid treatment inhibited formation of the 
angiogenic network in vitro and also resulted in downregulation of VEGF (Hossain, Banik, \& Ray, 2012). Similar results were found in in vitro and in vivo studies in hepatocellular carcinoma (Shen, et al., 2014; G. C. Xu, et al., 2012) and in gastric cancer (Tu, et al., 2003), where Survivin inhibition greatly affected tumorigenicity and angiogenesis.

\section{Role of IAPs in hypoxia and angiogenesis:}

In cancer, tissue oxygenation is severely impaired because tumor cells rapidly outgrow their blood supply resulting in a condition known as hypoxia. A small sub-population of tumor cells develop the ability to survive in these hypoxic conditions and also simultaneously become more resistant to chemotherapy and radiotherapy (Muz, de la Puente, Azab, \& Azab, 2015). Hypoxia inducible factors (HIFs) are a family of transcriptional complexes that are major sensors of hypoxia and regulate how cancer cells respond in this oxygen-deprived microenvironment. It is now established that there exists a close relationship between angiogenesis and hypoxia as HIF activation is an important stimulus for blood vessel growth. HIFs have been known to regulate various pro- and anti-angiogenic factors like VEGF (Hashimoto \& Shibasaki, 2015; Krock, Skuli, \& Simon, 2011; Lv, et al., 2017). In addition, HIFs have been reported to up-regulate expression of various IAP genes. Chen et al. studied the expression of HIF $\alpha$ and Survivin in non-small cell lung cancer and reported that HIFa binds to the promotor of the Survivin gene and increases its transcription (Y. Q. Chen, Zhao, \& Li, 2009). Additionally, HIFa-mediated up-regulation of Survivin has been reported in cervical cancer (Bai, Ge, Lu, Qian, \& Xu, 2013) and in gastric cancer, where this upregulation correlated with increased resistance to cisplatin (X. P. Sun, et al., 2014). These studies suggest that HIF-induced expression of IAP proteins could confer resistance to hypoxia- 
induced apoptosis, simultaneously conferring on them resistance to treatment-induced apoptosis.

\subsection{Metabolic Reprogramming}

In order to sustain cell proliferation, tumor cells need to alter their metabolism and this has now been considered to be an emerging hallmark of cancer. It has long been known that cancer cells reprogram their metabolism by switching to glycolysis for energy production even in the presence of oxygen, and this phenomenon is called the Warburg effect. In neuroblastoma, a type of brain cancer that is predominant in children and frequently shows amplification of the Survivin gene through gain of chromosome 17q. Hagenbuchner et al. have shown that Survivin overexpression results in reprogramming of cancer metabolism and causes cells to shift to glycolysis from oxidative phosphorylation (OXPHOS) for energy production. Survivin mediates these effects by altering the mitochondrial fission and fusion machinery, resulting in reorganization of the mitochondrial network (Hagenbuchner, Kuznetsov, Obexer, \& Ausserlechner, 2013). The same group has also demonstrated that the Survivin-induced shift to glycolysis in aerobic conditions can be therapeutically exploited using glycolysis inhibitors. The treatment of Survivin overexpressing cells with 2-deoxy-D-glucose (2DG), which is a glucose analogue and acts by inhibiting the production of glucose-6-phosphate from glucose, resulted in autophagy-mediated degradation of Survivin and re-fusion of the mitochondrial networks (Hagenbuchner, Kiechl-Kohlendorfer, Obexer, \& Ausserlechner, 2016). Rivadeneira et al. reported that Survivin also plays a role in mitochondrial OXPHOS in prostate adenocarcinoma cells. They found that Survivin cooperates with Hsp90 to stabilize the OXPHOS complex. siRNAmediated silencing of Survivin resulted in defective metabolic bioenergetics, increased OXPHOS 
metabolites and reduced $\mathrm{O}_{2}$ consumption (Rivadeneira, et al., 2015). These studies show that Survivin can influence both glycolysis and OXPHOS.

\subsection{Immune Evasion}

Another of the most striking features of tumor cells is their ability to resist eradication by the host immune system which enables cancer progression and survival of micro-metastatic cells in the circulation leading to disease dissemination. As discussed in previous sections, IAPs play an important role in regulating the NFKB pathway, a central regulator of inflammation and immunity. In response to infectious pathogen-associated molecular patterns (PAMPs) and sterile damage-associated molecular patterns (DAMPs), NFKB activation is initiated by activation of pattern recognition receptors (PRRs) such as the toll-like receptors (TLRs), nod-like receptor (NLR) family and RIG-like receptor family (RLR), resulting in the transcription of various proinflammatory cytokines, chemokines and interferons. IAPs regulate activation of PRRs through their interaction with TRAF-2 and -3 and their E3-ligase ubiquitylation activity (Beug, Cheung, LaCasse, \& Korneluk, 2012; Estornes \& Bertrand, 2015). Additionally, IAPs regulate the adaptive immune response, functioning as negative regulators of $B$ lymphocytes via their role in the noncanonical NFאB pathway, with clAP depletion reported to augment B cell proliferation and survival (Zarnegar, et al., 2008).

The IAP family member Livin (ML-IAP) is expressed as two isoforms known as Livin $\alpha$ and Livin $\beta$, both of which have unique roles in regulating apoptosis and immunity. Livin can also be cleaved by caspases to produce a truncated form (tLivin), which has a paradoxical pro-apoptotic function. Interestingly, the Livin $\beta$ isoform has been reported to protect cells against natural killer (NK) cellmediated killing when not cleaved. However, NK cells can themselves induce cleavage of Livin to 
the pro-apoptotic tLivin which can then inhibit tumor growth (Abd-Elrahman, et al., 2009; Nachmias, et al., 2007).

\section{Targeting IAP proteins for cancer therapy}

Due to the elevated expression of IAP proteins in many different cancers and their diverse role in tumorigenesis, they have long been considered attractive therapeutic targets. Although antisense approaches have been explored, the leading current strategies to target IAPs involve agents that mimic the interaction of the endogenous IAP antagonist SMAC with IAPs. The development of SMAC mimetic compounds, combinatorial therapies with these compounds and on-going clinical trials have been recently reviewed (Cong, et al., 2019). We summarize some of the key points below.

\section{SMAC mimetics}

The endogenous IAP inhibitor SMAC was discovered after several studies reported the presence of pro-apoptotic proteins Reaper, Head Involution Defective (HID) and Grim in Drosophila that could directly interact with the IAP proteins and block their caspase inhibitory activity. This led to the discovery of their mammalian counterparts. Along with cytochrome $c$ and dATP, SMAC was discovered in mitochondrial extracts which could selectively enhance caspase- 9 activity by neutralizing the effects of IAP proteins. It was also discovered in co-immunoprecipitation studies looking for binding partners of XIAP and was found to also interact with CIAP1/2. SMAC was also shown to be released into the cytosol from mitochondria during apoptosis (Du, Fang, Li, Li, \& Wang, 2000; Verhagen, et al., 2000). 
Structural analyses revealed that the $\mathrm{N}$ terminus of SMAC contains a 55 residue mitochondrial targeting sequence that is cleaved to expose a sequence of four hydrophobic amino acids (AVPI) that are required for binding to the IAP proteins. This tetra-peptide sequence binds to a conserved surface groove on the BIR3 domain of XIAP, and this sequence must be exposed for the binding to occur (Z. Liu, et al., 2000; Shi, 2002). The knowledge that SMAC binding to IAP requires only four amino acids and also the precise structural understanding of this interaction stimulated interest in development of small molecule inhibitors that could bind to this pocket. SMAC peptides derived from this sequence were shown to bind to IAP proteins and abrogate their activity and also sensitize cancer cells to chemotherapeutic agents (Franklin, et al., 2003; Vucic, et al., 2002). Furthermore, in vivo studies demonstrated that SMAC mimetic peptides could enhance TRAIL-induced apoptosis in xenograft models (Simone Fulda, Wick, Weller, \& Debatin, 2002). These studies were the first to prove that mimicking the $\mathrm{N}$-terminus of SMAC could be an effective way to target IAPs and paved the way for the development of complex fusion and other synthetic peptides (A Elsawy, G Tikhonova, Martin, \& Walker, 2015; Elsawy, Martin, Tikhonova, \& Walker, 2013).

However, these SMAC-based peptides did not possess the pharmacological properties to be clinically developed. Therefore, the next development was generation of small molecule compounds that mimic the 4 amino acid AVPI IAP-binding motif. This was achieved by the introduction of non-natural amino acids and various chemical substitutions in order to increase cell permeability and potency (Kipp, et al., 2002; Oost, et al., 2004). The first monovalent IAP antagonist developed by Sun et al. was a non-peptidic SMAC mimetic which was conformationally constrained and was 23 times more potent than the natural SMAC peptide ( $\mathrm{H}$. Sun, Nikolovska- 
Coleska, Yang, Xu, Liu, et al., 2004). Several other SMAC mimetic compounds have now been developed that induce apoptosis in cancer cells (Cohen, et al., 2009; H. Sun, Nikolovska-Coleska, Yang, Xu, Tomita, et al., 2004; B. Zhang, et al., 2008; Zobel, et al., 2006).

Most of these monovalent IAP antagonists bind to the BIR3 domain of IAPs; however, as mentioned earlier, the BIR2 domain also plays an important role in caspase inhibition. Therefore, a third generation of IAP antagonists known as bivalent mimetics were developed consisting of two of the IAP binding tetra peptide motifs joined by a linker enabling them to simultaneously bind both the BIR2 and BIR3 domains of XIAP. One such bivalent SMAC mimetic (SM-164) was found to be several orders of magnitude more potent than its monovalent counterpart and was found to induce apoptosis at concentrations as low as 1nM in leukemia cell lines (H. Sun, et al., 2007).

The same group also looked at the ability of SMAC mimetic small molecule compounds to inhibit cIAP1/2. They investigated the potential of two different SMAC mimetics, monovalent SM-122 and bivalent SM-146 and reported that removal of cIAP1/2 alone is not enough for TNF $\alpha$ induced apoptosis and that XIAP plays an important role in this process (J. Lu, et al., 2008). The recently developed AZD5582 was shown to bind to the BIR2 domains of XIAP and the BIR3 domains of CIAP1/2 and XIAP. It also resulted in degradation of cIAP1 and induced apoptosis in breast cancer cell lines (Hennessy, et al., 2013). Several other bivalent SMAC mimetics have now been developed by different chemical modifications between the linker regions and were reported to be highly potent (Zide Chen, et al., 2018; W. Li, et al., 2011; Yuefeng Peng, et al., 2011; Perez, et al., 2015; Sheng, et al., 2013). 
Because on their varied roles in regulating both the innate and adaptive immune system responses, IAPs are now being considered as targets for developing immunotherapy-based treatments in different cancers. In metastatic melanoma patients treated with anti-tumor vaccines, Livin was reported to stimulate a cellular and humoral immune response and is therefore a potential target for promoting immune-mediated tumor destruction (J. Schmollinger \& Dranoff, 2004; J. C. Schmollinger, et al., 2003). Similar reports have also been published for Survivin with it being capable of inducing tumor-specific CD8+ and CD4+ T cells in colorectal cancer and cytotoxic $\mathrm{T}$ cells in chronic lymphatic leukemia, breast cancer and melanoma (Andersen, Pedersen, Becker, \& thor Straten, 2001; Andersen, Pedersen, Capeller, et al., 2001; Casati, et al., 2003). Furthermore, various studies have shown that IAP antagonists have costimulatory effects on T cells and can enhance the potency of tumor vaccines (Dougan, et al., 2010). Importantly, these agents have been reported to synergize with immune checkpoint inhibitors: Beug et al. were the first to report synergism between IAP antagonists and immune checkpoint inhibitors in a mouse model of glioblastoma in which monotherapy was ineffective. They reported that combined treatment with LCL161, which is an orally bioavailable IAP inhibitor targeting XIAP and CIAP1/2, and anti-PD1/CTLA4 antibodies significantly increased survival rates of the mice. This synergy was reported to be dependent upon TNF $\alpha$ inducing cytotoxic T cell activity and also type I interferon signaling (Beug, et al., 2017). Similar findings were reported in mouse models of multiple myeloma, where the median survival of the mice co-treated with LCL161 and anti-PD1 antibody increased to 33 days from 14 days for the treatment with the antiPD1 antibody alone; moreover, this combination was curative in all mice that completed this combinatory treatment for 2 weeks (Chesi, et al., 2016). Since PD1 expression diminishes production of TNF $\alpha$ and IAP antagonists sensitize tumor cells to cytotoxic T cell-derived TNF $\alpha$, 
combining these two strategies can enhance T cell-mediated killing of tumor cells (Kearney, et al., 2017).

The advancements in the development of IAP antagonists along with the increased understanding of IAP protein biology has paved the way for the use of IAP antagonists in clinical trials. Both monovalent and bivalent SMAC mimetics have entered clinical trials and are being tested to determine their pharmacological, dosing, and safety characteristics. Additionally, a nonpeptidomimetic orally administered IAP antagonist (ASTX-660) has also been developed by fragment-based design and is currently in early-phase clinical trials (Derakhshan, et., 2017). The list of IAP antagonists in Phase II clinical trials is summarized in Table 2.

\subsection{Biomarkers for treatment response to SMAC mimetics}

For the effective implementation of SMAC based therapies in the clinic, identification of biomarkers to identify patients most likely to benefit from treatment with them are critical. It has been reported that the anti-tumor effects of SMs depends upon the ability of tumors to produce and respond to TNF $\alpha$ or any TNF $\alpha$-associated death ligand, and tumors that are unable to carry out either of these functions are most likely to be resistant to SM based therapies (Gaither, et al., 2007; Petersen, et al., 2007). Preclinical studies in breast cancer xenograft models assessing potential biomarkers of treatment response suggested that plasma levels of TNF $\alpha$ and cleaved and total cytokeratin-18 (a marker of caspase-dependent cell death) may be useful (Sumi, et al., 2013). However, in a clinical trial of Debio 1143 in patients with advanced cancer, plasma levels of TNF $\alpha$ and cytokeratin-18 along with other inflammatory markers like IL-8 and CCL2 showed no apparent relationship with treatment response. (Hurwitz, et al., 2015). 
In a recent study, Zinngrebe et al. reported the identification of gene expression markers that could help in stratifying patients that were particularly sensitive to SMs. This was done in B-cell acute lymphoblastic leukemia (BCP-ALL) and found four commonly predictive genes, which were TSPAN7, DIPK1C, MTX2 and TNFRSF1A, the latter encoding TNFR1 (Zinngrebe, et al., 2020). Additionally, it was recently reported that systems biology approaches to mathematically model apoptosis competency may be useful for predicting response to IAP antagonists; these algorithms correlated with efficacy in CRC xenograft models and indicated that resistance to IAP antagonists can be overcome by combining with standard-of-care chemotherapy (Crawford, et al., 2018).

These studied highlight the need for the development of predictive biomarkers for IAP antagonists that could be used to identify patients that would benefit from these treatments and also whether these therapies could be added to standard-of-care chemotherapies.

\section{Conclusion}

As outlined above, there is extensive literature linking IAPs to different hallmarks of tumorigenesis: sustained proliferation, invasion and metastasis, angiogenesis, evasion of cell death, evasion of anti-tumor immunity and tumor-promoting alterations in metabolism. While their role in regulating apoptosis is well studied, a deeper understanding of their involvement in other cellular processes is needed in order to fully exploit therapeutic targeting of IAPs. Overexpression of IAPs in a number of cancers makes it an attractive target, and there have been a number of agents developed which are showing promise in clinical trials. For clinical approval, it will be important to identify predictive biomarkers to enable selection of the target patient population. While signals of single agent activity have been observed, it is likely that anti-IAP therapies have their greatest potential in combination with other agents, including standard-ofcare chemotherapeutic agents, targeted agents and radiotherapy. 


\begin{tabular}{|c|c|c|c|c|c|c|}
\hline \multicolumn{7}{|c|}{ Acute Myeloid Leukemia } \\
\hline Biospecimen analyzed & $\begin{array}{c}\text { Number of } \\
\text { patients }\end{array}$ & $\begin{array}{l}\text { IAP protein } \\
\text { studied }\end{array}$ & Expression & $\begin{array}{l}\text { mRNA/protei } \\
\text { n level }\end{array}$ & Prognosis/Comments & Reference \\
\hline $\begin{array}{l}\text { Bone marrow } \\
\text { aspirates }\end{array}$ & 120 & ClAP2 & High & mRNA & Poor OS (part of a 3 gene signature) & Hess, et al., 2007 \\
\hline Blood & 78 & XIAP & Low & Protein & Better OS \& Remission duration & Tamm, et al., 2000 \\
\hline Blood \& bone marrow & 62 & $\begin{array}{c}\text { XIAP } \\
\text { Survivin, cIAP1 }\end{array}$ & $\begin{array}{c}\text { Low } \\
-\end{array}$ & $\begin{array}{l}\text { Protein } \\
\text { Protein }\end{array}$ & $\begin{array}{c}\text { Better OS } \\
\text { No prognostic impact }\end{array}$ & Tamm, et al., 2004 \\
\hline Blood & 172 & XIAP, Survivin & - & Protein & No prognostic impact & Carter, et al., 2003 \\
\hline Blood \& bone marrow & 56 & $\begin{array}{c}\text { SMAC/Diablo } \\
\text { Survivin } \\
\text { XIAP, cIAP1, cIAP2 }\end{array}$ & $\begin{array}{l}\text { High } \\
\text { Low } \\
-\end{array}$ & $\begin{array}{l}\text { Protein } \\
\text { Protein } \\
\text { Protein }\end{array}$ & $\begin{array}{l}\text { Better OS, No impact on DFS } \\
\text { Better OS, No impact on DFS } \\
\text { No impact on OS \& DFS }\end{array}$ & Pluta, et al., 2015 \\
\hline \multicolumn{7}{|c|}{ Bladder Cancer } \\
\hline Tissue & 176 & XIAP & High & Protein/mRNA & $\begin{array}{l}\text { Lower RFS, Independent prognostic } \\
\text { factor for recurrence }\end{array}$ & Ming, Tao, Yin, \& Na, 2007 \\
\hline Tissue & 102 & clAP1, clAP2 & High (nuclear) & Protein & Poor OS \& RFS & X. Che, et al., 2012 \\
\hline Tissue & 105 & $\begin{array}{l}\text { XIAP, cIAP1, cIAP2, } \\
\text { Survivin }\end{array}$ & High & Protein & Reduced RFS & X. Chen, at al., 2013 \\
\hline Tissue/Urine & - & Survivin & High & Protein/mRNA & $\begin{array}{c}\text { Poor prognoses } \\
\text { predictor for OS, RFS and PFS } \\
\text { (Systematic Review) }\end{array}$ & Jeon, Kim, Kwak, Kim, \& Ku, 2013 \\
\hline \multicolumn{7}{|c|}{ Breast Cancer } \\
\hline FFPE Tissue & 102 & XIAP, Smac & High (nuclear) & Protein & Poor OS & Y. Zhang, et al., 2011 \\
\hline Tissue & 293 & Survivin & High (nuclear) & Protein & Independent predictor of OS \& RFS & Kennedy, et al., 2003 \\
\hline Tissue & 92 & $\begin{array}{l}\text { XIAP, cIAP1, cIAP2, } \\
\text { survivin }\end{array}$ & Low & Protein & Longer PFS, No impact on OS & P. Pluta, et al., 2015 \\
\hline \multicolumn{7}{|c|}{ Pancreatic Cancer } \\
\hline & & & & & & \\
\hline
\end{tabular}




\begin{tabular}{|c|c|c|c|c|c|c|}
\hline Cell lines & - & CIAP2 & High & mRNA & $\begin{array}{c}\text { Resistance to chemotherapeutic } \\
\text { drugs }\end{array}$ & $\begin{array}{l}\text { Lopes, Gangeswaran, McNeish, } \\
\text { Wang, \& Lemoine, } 2007\end{array}$ \\
\hline Tissue & 33 & ClAP1, clAP2 & High & Protein/mRNA & $\begin{array}{l}\text { Co-expression predicts worse } \\
\text { prognosis, clAP2 levels increase } \\
\text { during disease progression }\end{array}$ & Esposito, et al., 2007 \\
\hline Tissue & 89 & $\begin{array}{l}\text { XIAP associated } \\
\text { factor (XAF1) }\end{array}$ & Low & Protein & $\begin{array}{c}\text { Shorter OS, Independent predictor } \\
\text { of survival }\end{array}$ & J. Huang, et al., 2010 \\
\hline \multicolumn{7}{|c|}{ Renal Cell Carcinoma } \\
\hline Tissue & 109 & XIAP & High & Protein & $\begin{array}{l}\text { Correlates with tumour stage, } \\
\text { shorter DFS }\end{array}$ & Mizutani, et al., 2007 \\
\hline FFPE Tissue & 145 & XIAP & High & Protein & $\begin{array}{l}\text { Correlates with tumour stage, } \\
\text { postoperative survival }\end{array}$ & Ramp, et al.,2004 \\
\hline \multicolumn{7}{|c|}{ Non-small cell Lung Cancer } \\
\hline $\begin{array}{l}\text { FFPE tissue (advanced } \\
\text { stage tumours) }\end{array}$ & 55 & $\mathrm{XIAP}, \mathrm{CIAP} 1, \mathrm{CIAP} 2$ & - & Protein & $\begin{array}{c}\text { No impact on OS \& PFS, response to } \\
\text { chemotherapy }\end{array}$ & Ferreira et al., 2001 \\
\hline $\begin{array}{l}\text { FFPE tissue (early } \\
\text { stage tumours) }\end{array}$ & 144 & XIAP & High & Protein & Longer OS & Ferreira et al., 2001 \\
\hline \multicolumn{7}{|c|}{ Colorectal Cancer } \\
\hline Tissue & 96 & XIAP & High & mRNA/Protein & $\begin{array}{c}\text { Correlates with tumour } \\
\text { differentiation, stage and invasion, } \\
\text { DFS \& OS }\end{array}$ & $\begin{array}{c}\text { Xiang, Wen, Wang, Chen, \& Liu, } \\
2009\end{array}$ \\
\hline Tissue & 106 & ClAP2 & High & Protein & Shorter OS & Krajewska, et al., 2005 \\
\hline \multicolumn{7}{|c|}{ Cervical Cancer } \\
\hline Cell lines/Tissues & 70 & CIAP1 & High (nuclear) & Protein & $\begin{array}{l}\text { Correlation with resistance to } \\
\text { radiation induced cell death, } \\
\text { reduced OS \& PFS }\end{array}$ & Imoto, et al., 2002 \\
\hline \multicolumn{7}{|c|}{ MALT Lymphoma } \\
\hline Cell line & - & CIAP2 & - & Protein & $\begin{array}{c}\text { Fusion protein with MALT } \\
\text { associated with advanced stage } \\
\text { disease }\end{array}$ & Rosebeck, et al., 2011 \\
\hline \multicolumn{7}{|c|}{ Hepatocellular carcinoma } \\
\hline Tissue & 80 & XIAP, XAF1 & High & mRNA & $\begin{array}{l}\text { Shorter OS, XIAP to XAF1 ratio } \\
\text { correlates with reduced OS }\end{array}$ & Augello, et al., 2009 \\
\hline \multicolumn{7}{|c|}{ Gastric adenocarcinoma } \\
\hline Tissue & 46 & XIAP, XAF1 & High & mRNA & $\begin{array}{c}\text { XIAP to XAF1 ratio correlated with } \\
\text { reduced OS }\end{array}$ & Shibata, et al., 2007 \\
\hline
\end{tabular}

Table 1: IAP expression and correlation to prognosis 


\begin{tabular}{|c|c|c|c|c|c|c|c|c|c|}
\hline Agent & Condition & Combination & $\begin{array}{l}\text { Number } \\
\text { enrolled }\end{array}$ & $\begin{array}{l}\text { NCT / EudraCT } \\
\text { Number }\end{array}$ & $\begin{array}{l}\text { Study } \\
\text { Start }\end{array}$ & $\begin{array}{c}\text { Study } \\
\text { Completion }\end{array}$ & Status & $\begin{array}{c}\text { Conclusions/Findi } \\
\text { ngs }\end{array}$ & Reference \\
\hline \multirow{5}{*}{$\begin{array}{c}\text { Debio } \\
1143\end{array}$} & $\begin{array}{l}\text { Squamous Cell Carcinoma of the Head and } \\
\text { Neck }\end{array}$ & $\begin{array}{c}\text { Cisplatin + } \\
\text { Radiotherapy }\end{array}$ & 110 & $\begin{array}{l}\text { NCT02022098 / } \\
\text { 2013-000044-25 }\end{array}$ & Oct-13 & Apr-20 & $\begin{array}{l}\text { Active, not } \\
\text { recruiting }\end{array}$ & $\begin{array}{c}\text { Improved } \\
\text { locoregional } \\
\text { control and PFS, } \\
\text { good tolerability }\end{array}$ & $\begin{array}{l}\text { Bourhis et } \\
\text { al., } 2019\end{array}$ \\
\hline & Solid Tumors & Nivolumab & 72 & NCT04122625 & Apr-19 & Jan-23 & Recruiting & - & - \\
\hline & $\begin{array}{l}\text { Squamous Cell Carcinoma of the Head and } \\
\text { Neck }\end{array}$ & Cisplatin & 24 & 2014-004655-31 & Aug-15 & Jul-18 & Completed & $\begin{array}{l}\text { Good distribution } \\
\text { into tumours, } \\
\text { targeted CIAP1, } \\
\text { increased CD8+ } \\
\text { lymphocytes and } \\
\text { PD-1/PD-L1 } \\
\text { positive immune } \\
\text { cells }\end{array}$ & $\begin{array}{l}\text { Gomez- } \\
\text { Roca et al., } \\
2019\end{array}$ \\
\hline & Solid Tumors & Nivolumab & 69 & $2018-003546-16$ & May-19 & Ongoing & Recruiting & - & - \\
\hline & Epithelial Ovarian & $\begin{array}{l}\text { Carbolplatin + } \\
\text { Paclitaxel }\end{array}$ & 35 & 2015-005137-42 & Jun-16 & Jan-18 & $\begin{array}{l}\text { Terminated } \\
\text { early }\end{array}$ & $\begin{array}{l}\text { Underdosing of } \\
\text { paclitaxel in } \\
\text { combination arm } \\
\text { revealed by PK } \\
\text { analysis }\end{array}$ & \\
\hline \multirow{4}{*}{ LCL161 } & Recurrent or refractory Plasma Cell Myeloma & $\begin{array}{l}\text { Cyclophosphami } \\
\text { de }\end{array}$ & 25 & NCT01955434 & Nov-13 & Jun-17 & Completed & - & - \\
\hline & $\begin{array}{c}\text { Polycythemia Vera, Post-Polycythemic } \\
\text { Myelofibrosis Phase, Primary Myelofibrosis, } \\
\text { Secondary Myelofibrosis }\end{array}$ & Monotherapy & 40 & NCT02098161 & Dec-14 & Dec-21 & Recruiting & $\begin{array}{l}\text { Reported a } 30 \% \\
\text { response rate in } \\
\text { treatment } \\
\text { resistant } \\
\text { population }\end{array}$ & $\begin{array}{l}\text { Pemmaraju } \\
\text { et al., } 2018\end{array}$ \\
\hline & Small Cell Lung Cancer, Ovarian Cancer & Topotecan & 52 & NCT02649673 & Mar-16 & Jul-19 & Recruiting & - & - \\
\hline & Triple Negative Breast Cancer & Paclitaxel & 209 & $2012-000677-23$ & Aug-12 & Sep-14 & Completed & $\begin{array}{l}\text { Addition of LCL161 } \\
\text { did not improve } \\
\text { pathological CR, } \\
\text { TNFa gene } \\
\text { signature } \\
\text { associated with } \\
\text { higher response } \\
\text { rates }\end{array}$ & $\begin{array}{l}\text { Bardia et } \\
\text { al., 2018; } \\
\text { Parton et } \\
\text { al., } 2015\end{array}$ \\
\hline
\end{tabular}




\begin{tabular}{|c|c|c|c|c|c|c|c|c|c|}
\hline \multirow[t]{2}{*}{ ASTX660 } & Solid Tumors & Monotherapy & 230 & NCT02503423 & Jul-15 & Oct-21 & Recruiting & $\begin{array}{l}\text { Preliminary results } \\
\text { suggest that it } \\
\text { shows activity in a } \\
\text { T cell lymphoma } \\
\text { cohort, } \\
\text { manageable safety } \\
\text { profile }\end{array}$ & $\begin{array}{l}\text { Mehta, et } \\
\text { al., } 2019\end{array}$ \\
\hline & $\begin{array}{l}\text { Relapsed or Refractory Peripheral T-cell } \\
\text { Lymphoma (PTCL), Cutaneous T-cell } \\
\text { Lymphoma (CTCL), Adult T-cell } \\
\text { Leukemia/Lymphoma (ATLL) }\end{array}$ & Monotherapy & 61 & NCT04362007 & Apr-20 & Sept-24 & Recruiting & & \\
\hline \multirow{6}{*}{$\begin{array}{c}\text { Birinapa } \\
\text { nt }\end{array}$} & Solid Tumors & Pembrolizumab & 135 & NCT02587962 & Aug-17 & Jun-21 & Terminated & $\begin{array}{l}\text { Lack of clinical } \\
\text { benefit, } \\
\text { Preliminary results } \\
\text { suggest that the } \\
\text { combination with } \\
\text { pembrolizumab is } \\
\text { safe and tolerable }\end{array}$ & $\begin{array}{l}\text { Schilder et } \\
\text { al., } 2019\end{array}$ \\
\hline & Myelodysplastic Syndrome & 5-Azacitidine & 21 & NCT01828346 & Jun-13 & Nov-15 & $\begin{array}{l}\text { Completed } \\
\text { No results }\end{array}$ & & \\
\hline & $\begin{array}{l}\text { Myelodysplastic Syndrome (MDS), Chronic } \\
\text { Myelomonocytic Leukemia (CMML) }\end{array}$ & $\begin{array}{l}\text { Azacitidine (AZA) } \\
\text { or placebo }\end{array}$ & 118 & NCT02147873 & Jun-14 & Jun-16 & $\begin{array}{l}\text { Terminated } \\
\text { early }\end{array}$ & $\begin{array}{c}\text { Response rate of } \\
\text { combination not } \\
\text { superior to AZA } \\
\text { alone, serious and } \\
\text { adverse events } \\
\text { rate higher in } \\
\text { birinapant arm }\end{array}$ & $\begin{array}{l}\text { Donnellan, } \\
\text { et al., } 2016\end{array}$ \\
\hline & Solid Tumors & $\begin{array}{l}\text { Carboplatin/Pacli } \\
\text { taxel, Irinotecan, } \\
\text { Docetaxel, } \\
\text { Gemcitabine, } \\
\text { liposomal } \\
\text { doxorubicin } \\
\text { (multi-arm) }\end{array}$ & 176 & NCT01188499 & Oct-10 & Mar-14 & Completed & $\begin{array}{l}\text { Combination with } \\
\text { irinotecan } \\
\text { demonstrated } \\
\text { clinical benefit in } \\
\text { irinotecan } \\
\text { relapsed/refractor } \\
\text { y patients with } \\
\text { colorectal cancer }\end{array}$ & $\begin{array}{l}\text { Senzer et } \\
\text { al., } 2013\end{array}$ \\
\hline & $\begin{array}{l}\text { Epithelial Ovarian Cancer, Peritoneal } \\
\text { Neoplasms or Fallopian Tube Neoplasms }\end{array}$ & Monotherapy & 11 & NCT01681368 & Aug-12 & Apr-14 & $\begin{array}{l}\text { Terminated } \\
\text { early }\end{array}$ & $\begin{array}{l}\text { Lack of clinical } \\
\text { benefit after } \\
\text { treatment with } \\
\text { birinapant }\end{array}$ & $\begin{array}{l}\text { Noonan et } \\
\text { al., } 2016\end{array}$ \\
\hline & Acute Myelogenous Leukemia & Monotherapy & 7 & NCT01486784 & Nov-11 & Ongoing & Terminated & & \\
\hline
\end{tabular}


Table 2: IAP antagonists in Phase II clinical trials 


\section{REFERENCES:}

A Elsawy, M., G Tikhonova, I., Martin, L., \& Walker, B. (2015). Smac-derived Aza-peptide as an aminopeptidase-resistant XIAP BIR3 antagonist. Protein and peptide letters, 22, 836-843.

Abd-Erahman, I., Hershko, K., Neuman, T., Nachmias, B., Perlman, R., \& Ben-Yehuda, D. (2009). The inhibitor of apoptosis protein Livin (ML-IAP) plays a dual role in tumorigenicity. Cancer Res, $69,5475-5480$

Ahn, S., \& Park, H. (2010). XIAP is essential for shear stress-enhanced Tyr-576 phosphorylation of FAK. Biochem Biophys Res Commun, 399, 256-261. Altieri, D. C. (2004). Molecular circuits of apoptosis regulation and cell division control: the survivin paradigm. J Cell Biochem, 92, 656-663. Ambrosini, G., Adida, C., \& Altieri, D. C. (1997). A novel anti-apoptosis gene, survivin, expressed in cancer and lymphoma. Nature medicine, 3, 917. Andersen, M. H., Pedersen, L. Ø., Becker, J. C., \& thor Straten, P. (2001). Identification of a cytotoxic T lymphocyte response to the apoptosis inhibitor protein survivin in cancer patients. Cancer research, 61, 869-872.

Andersen, M. H., Pedersen, L. Ф., Capeller, B., Bröcker, E.-B., Becker, J. C., \& thor Straten, P. (2001). Spontaneous cytotoxic T-cell responses against survivinderived MHC class I-restricted T-cell epitopes in situ as well as ex vivo in cancer patients. Cancer research, 61, 5964-5968.

Augello, C. Caruso, L., Maggioni, M., Donadon, M., Montorsi, M., Santambrogio, R., Torzilli, G., Vaira, V., Pellegrini, C., Roncalli, M., Coggi, G., \& Bosari, S. (2009). Inhibitors of apoptosis proteins (IAPs) expression and their prognostic significance in hepatocellular carcinoma. BMC Cancer, 9, 125.

Avizienyte, E., \& Frame, M. C. (2005). SrC and FAK signalling controls adhesion fate and the epithelial-to-mesenchymal transition. Curr Opin Cell Biol, 17, 542547.

Bai, H., Ge, S., Lu, J., Qian, G., \& Xu, R. (2013). Hypoxia inducible factor-1alpha-mediated activation of survivin in cervical cancer cells. J Obstet Gynaecol Res, $39,555-563$.

Bardia, A., Parton, M., Kümmel, S., Estévez, L. G., Huang, C.-S., Cortés, J., Ruiz-Borrego, M., Telli, M. L., Martin-Martorell, P., \& López, R. (2018). Paclitaxel with inhibitor of apoptosis antagonist, LCL161, for localized triple-negative breast cancer, prospectively stratified by gene signature in a biomarker-driven neoadjuvant trial. J Clin Oncol, 36, 3126-3133.

Bartke, T., Pohl, C., Pyrowolakis, G., \& Jentsch, S. (2004). Dual Role of BRUCE as an Antiapoptotic IAP and a Chimeric E2/E3 Ubiquitin Ligase. Molecular cell, 14 801-811.

Bashyam, M. D., Bair, R., Kim, Y. H., Wang, P., Hernandez-Boussard, T., Karikari, C. A., Tibshirani, R., Maitra, A., \& Pollack, J. R. (2005). Array-based comparative genomic hybridization identifies localized DNA amplifications and homozygous deletions in pancreatic cancer. Neoplasia (New York, NY), 7,556 .

Behrends, C., \& Harper, J. W. (2011). Constructing and decoding unconventional ubiquitin chains. Nat Struct Mol Biol, 18, 520-528.

Berthelet, J., \& Dubrez, L. (2013). Regulation of Apoptosis by Inhibitors of Apoptosis (IAPs). Cells, 2, 163-187.

Bertrand, M. J., Milutinovic, S., Dickson, K. M., Ho, W. C., Boudreault, A., Durkin, J., Gillard, J. W., Jaquith, J. B., Morris, S. J., \& Barker, P. A. (2008). clAP1 and cIAP2 facilitate cancer cell survival by functioning as E3 ligases that promote RIP1 ubiquitination. Mol Cell, 30, 689-700.

Beug, S. T., Beauregard, C. E., Healy, C., Sanda, T., St-Jean, M., Chabot, J., Walker, D. E., Mohan, A., Earl, N., Lun, X., Senger, D. L., Robbins, S. M., Staeheli, P. Forsyth, P. A., Alain, T., LaCasse, E. C., \& Korneluk, R. G. (2017). Smac mimetics synergize with immune checkpoint inhibitors to promote tumour immunity against glioblastoma. Nat Commun, 8 .

Beug, S. T., Cheung, H. H., LaCasse, E. C., \& Korneluk, R. G. (2012). Modulation of immune signalling by inhibitors of apoptosis. Trends Immunol, 33, 535-545. Birkey Reffey, S., Wurthner, J. U., Parks, W. T., Roberts, A. B., \& Duckett, C. S. (2001). X-linked inhibitor of apoptosis protein functions as a cofactor in transforming growth factor-beta signaling. J Biol Chem, 276, 26542-26549.

Birnbaum, M., Clem, R., \& Miller, L. (1994). An apoptosis-inhibiting gene from a nuclear polyhedrosis virus encoding a polypeptide with Cys/His sequence motifs. Journal of virology, 68, 2521-2528.

Bourhis, J., Sun, X., Pointreau, Y., Sire, C., Le Tourneau, C., Coutte, A., Kaminsky-Forrett, M., Alfonsi, M., Boisselier, P., \& Martin, L. (2019). LBA65 Double-blind randomized phase II results comparing concurrent high-dose cisplatin chemorradiation (CRT) plus debio 1143 or placebo in high-risk patients with locally advanced squamous cell carcinoma of the head and neck (SCCHN): A GORTEC study. Annals of oncology, 30, mdz394. 062.

Cao, J., Qiu, J., Wang, X., Lu, Z., Wang, D., Feng, H., Li, X., Liu, Q., Pan, H., Han, X., Wei, J., Liu, S., \& Wang, L. (2018). Identification of microRNA-124 in regulation of Hepatocellular carcinoma through BIRC3 and the NF-kappaB pathway. J Cancer, 9, 3006-3015.

Carter, B. Z., Kornblau, S. M., Tsao, T., Wang, R.-Y., Schober, W. D., Milella, M., Sung, H.-G., Reed, J. C., \& Andreeff, M. (2003). Caspase-independent cell death in AML: caspase inhibition in vitro with pan-caspase inhibitors or in vivo by XIAP or Survivin does not affect cell survival or prognosis. Blood, 102, 4179-4186.

Cartier, J., Berthelet, J., Marivin, A., Gemble, S., Edmond, V., Plenchette, S., Lagrange, B., Hammann, A., Dupoux, A., Delva, L., Eymin, B., Solary, E., \& Dubrez, L. (2011). Cellular inhibitor of apoptosis protein-1 (cIAP1) can regulate E2F1 transcription factor-mediated control of cyclin transcription. J Biol Chem, 286, 26406-26417.

Casati, C., Dalerba, P., Rivoltini, L., Gallino, G., Deho, P., Rini, F., Belli, F., Mezzanzanica, D., Costa, A., \& Andreola, S. (2003). The apoptosis inhibitor protein survivin induces tumor-specific CD8+ and CD4+ T cells in colorectal cancer patients. Cancer research, 63, 4507-4515. 
Chandele, A., Prasad, V., Jagtap, J. C., Shukla, R., \& Shastry, P. R. (2004). Upregulation of survivin in G2/M cells and inhibition of caspase 9 activity enhances resistance in staurosporine-induced apoptosis. Neoplasia (New York, NY), 6, 29

Che, L., Yang, X., Ge, C., El-Amouri, S. S., Wang, Q. E., Pan, D., Herzog, T. J., \& Du, C. (2019). Loss of BRUCE reduces cellular energy level and induces autophagy by driving activation of the AMPK-ULK1 autophagic initiating axis. PLOS One, 14, e0216553.

Che, X., Yang, D., Zong, H., Wang, J., Li, X., Chen, F., Chen, X., \& Song, X. (2012). Nuclear clAP1 overexpression is a tumor stage- and grade-independent predictor of poor prognosis in human bladder cancer patients. Urol Oncol, 30, 450-456.

Chen, J., \& Chen, Z. J. (2013). Regulation of NF-kappaB by ubiquitination. Curr Opin Immunol, 25, 4-12.

Chen, P., Zhu, J., Liu, D. Y., Li, H. Y., Xu, N., \& Hou, M. (2014). Over-expression of survivin and VEGF in small-cell lung cancer may predict the poorer prognosis. Med Oncol, 31, 775 .

Chen, X., Wang, T., Yang, D., Wang, J., Li, X., He, Z., Chen, F., Che, X., \& Song, X. (2013). Expression of the IAP protein family acts cooperatively to predict prognosis in human bladder cancer patients. Oncology letters, 5, 1278-1284.

Chen, Y. Q., Zhao, C. L., \& Li, W. (2009). Effect of hypoxia-inducible factor-1alpha on transcription of survivin in non-small cell lung cancer. J Exp Clin Cancer Res, 28,29

Chen, Z., Chen, J., Liu, H., Dong, W., Huang, X., Yang, D., Hou, J., \& Zhang, X. (2018). The SMAC mimetic APG-1387 sensitizes immune-mediated cell apoptosis in hepatocellular carcinoma. Frontiers in pharmacology, $9,1298$.

Chen, Z., Naito, M., Hori, S., Mashima, T., Yamori, T., \& Tsuruo, T. (1999). A human IAP-family gene, apollon, expressed in human brain cancer cells. Biochemical and biophysical research communications, 264, 847-854.

Chesi, M., Mirza, N. N., Garbitt, V. M., Sharik, M. E., Dueck, A. C., Asmann, Y. W., Akhmetzyanova, I., Kosiorek, H. E., Calcinotto, A., Riggs, D. L., Keane, N., Ahmann, G. J., Morrison, K. M., Fonseca, R., Lacy, M. Q., Dingli, D., Kumar, S. K., Ailawadhi, S., Dispenzieri, A., Buadi, F., Gertz, M. A., Reeder, C. B., Lin, Y., Chanan-Khan, A. A., Stewart, A. K., Fooksman, D., \& Bergsagel, P. L. (2016). IAP antagonists induce anti-tumor immunity in multiple myeloma. Nat Med, 22, 1411-1420.

Cheung, H. H., Plenchette, S., Kern, C. J., Mahoney, D. J., \& Korneluk, R. G. (2008). The RING domain of cIAP1 mediates the degradation of RING-bearing inhibitor of apoptosis proteins by distinct pathways. Mol Biol Cell, 19, 2729-2740.

Cohen, F., Alicke, B., Elliott, L. O., Flygare, J. A., Goncharov, T., Keteltas, S. F., Franklin, M. C., Frankovitz, S., Stephan, J.-P., \& Tsui, V. (2009). Orally bioavailable antagonists of inhibitor of apoptosis proteins based on an azabicyclooctane scaffold. Journal of medicinal chemistry, 52, 1723-1730.

Colnaghi, R., Connell, C. M., Barrett, R. M., \& Wheatley, S. P. (2006). Separating the anti-apoptotic and mitotic roles of survivin. J Biol Chem, 281, 3345033456.

Cong, H., Xu, L., Wu, Y., Qu, Z., Bian, T., Zhang, W., Xing, C., \& Zhuang, C. (2019). Inhibitor of apoptosis protein (IAP) antagonists in anticancer agent discovery: Current status and perspectives. Journal of medicinal chemistry, 62, 5750-5772.

Connell, C. M., Colnaghi, R., \& Wheatley, S. P. (2008). Nuclear survivin has reduced stability and is not cytoprotective. J Biol Chem, 283, 3289-3296.

Crawford, N., Salvucci, M., Hellwig, C. T., Lincoln, F. A., Mooney, R. E., O'Connor, C. L., Prehn, J. H., Longley, D. B., \& Rehm, M. (2018). Simulating and predicting cellular and in vivo responses of colon cancer to combined treatment with chemotherapy and IAP antagonist Birinapant/TL32711. Cell Death Differ, 25, 1952-1966.

Crook, N. E., Clem, R. J., \& Miller, L. K. (1993). An apoptosis-inhibiting baculovirus gene with a zinc finger-like motif. Journal of virology, 67, $2168-2174$.

Dai, Z., Zhu, W.-G., Morrison, C. D., Brena, R. M., Smiraglia, D. J., Raval, A., Wu, Y.-Z., Rush, L. J., Ross, P., Molina, J. R., Otterson, G. A., \& Plass, C. (2003). A comprehensive search for DNA amplification in lung cancer identifies inhibitors of apoptosis cIAP1 and cIAP2 as candidate oncogenes. Human Molecular Genetics, 12, 791-801.

Darding, M., \& Meier, P. (2012). IAPs: guardians of RIPK1. Cell Death Differ, 19, 58-66.

Das, G., Shravage, B. V., \& Baehrecke, E. H. (2012). Regulation and function of autophagy during cell survival and cell death. Cold Spring Harb Perspect Biol, 4. Delvaeye, M., De Vriese, A., Zwerts, F., Betz, I., Moons, M., Autiero, M., \& Conway, E. M. (2009). Role of the 2 zebrafish survivin genes in vasculo-angiogenesis, neurogenesis, cardiogenesis and hematopoiesis. BMC Dev Biol, 9, 25

Deveraux, Q. L., \& Reed, J. C. (1999). IAP family proteins-suppressors of apoptosis. Genes \& development, 13, 239-252.

Deveraux, Q. L., Roy, N., Stennicke, H. R., Van Arsdale, T., Zhou, Q., Srinivasula, S. M., Alnemri, E. S., Salvesen, G. S., \& Reed, J. C. (1998). IAPs block apoptotic events induced by caspase-8 and cytochrome $c$ by direct inhibition of distinct caspases. The EMBO journal, 17, 2215-2223.

Deveraux, Q. L., Takahashi, R., Salvesen, G. S., \& Reed, J. C. (1997). X-linked IAP is a direct inhibitor of cell-death proteases. Nature, $388,300$.

Dogan, T., Harms, G. S., Hekman, M., Karreman, C., Oberoi, T. K., Alnemri, E. S., Rapp, U. R., \& Rajalingam, K. (2008). X-linked and cellular IAPs modulate the stability of C-RAF kinase and cell motility. Nat Cell Biol, 10, 1447-1455.

Donnellan, W. B., Diez-Campelo, M., Heuser, M., Ritchie, E. K., Skolnik, J., Font, P., \& Komrokji, R. S. (2016). A phase 2 study of azacitidine (5-AZA) with or without birinapant in subjects with higher risk myelodysplastic syndrome (MDS) or chronic myelomonocytic leukemia (CMML). In: American Society of Clinical Oncology.

Dougan, M., Dougan, S., Slisz, J., Firestone, B., Vanneman, M., Draganov, D., Goyal, G., Li, W., Neuberg, D., Blumberg, R., Hacohen, N., Porter, D., Zawel, L., \& Dranoff, G. (2010). IAP inhibitors enhance co-stimulation to promote tumor immunity. J Exp Med, 207, 2195-2206. 
Du, C., Fang, M., Li, Y., Li, L., \& Wang, X. (2000). Smac, a mitochondrial protein that promotes cytochrome c-dependent caspase activation by eliminating IAP inhibition. Cell, 102, 33-42.

Dubrez, L. \& Rajalingam, K. (2015). IAPs and cell migration. Semin Cell Dev Biol, 39, 124-131.

Duckett, C., Nava, V. E., Gedrich, R. W., Clem, R. J., Van Dongen, J. L., Gilfillan, M. C., Shiels, H., Hardwick, J. M., \& Thompson, C. B. (1996). A conserved family of cellular genes related to the baculovirus iap gene and encoding apoptosis inhibitors. The EMBO journal, 15, 2685-2694.

Ebner, P., Poetsch, I., Deszcz, L., Hoffmann, T., Zuber, J., \& Ikeda, F. (2018). The IAP family member BRUCE regulates autophagosome-lysosome fusion. Nat Commun, 9, 599 .

Eckelman, B. P., \& Salvesen, G. S. (2006). The human anti-apoptotic proteins cIAP1 and cIAP2 bind but do not inhibit caspases. J Biol Chem, 281, 3254-3260. Eckelman, B. P., Salvesen, G. S., \& Scott, F. L. (2006). Human inhibitor of apoptosis proteins: why XIAP is the black sheep of the family. EMBO Rep, 7, 988-994. Elmore, S. (2007). Apoptosis: a review of programmed cell death. Toxicologic pathology, 35, 495-516.

Elsawy, M. A., Martin, L., Tikhonova, I. G., \& Walker, B. (2013). Solid phase synthesis of Smac/DIABLO-derived peptides using a 'Safety-Catch'resin: Identification of potent XIAP BIR3 antagonists. Bioorganic \& medicinal chemistry, 21, 5004-5011.

Endoh, T., Tsuji, N., Asanuma, K., Yagihashi, A., \& Watanabe, N. (2005). Survivin enhances telomerase activity via up-regulation of specificity protein 1- and cMyc-mediated human telomerase reverse transcriptase gene transcription. Exp Cell Res, 305, 300-311.

Esposito, I., Kleeff, J., Abiatari, I., Shi, X., Giese, N., Bergmann, F., Roth, W., Friess, H., \& Schirmacher, P. (2007). Overexpression of cellular inhibitor of apoptosis protein 2 is an early event in the progression of pancreatic cancer. J Clin Pathol, 60, 885-895.

Estornes, Y., \& Bertrand, M. J. (2015). IAPs, regulators of innate immunity and inflammation. Semin Cell Dev Biol, 39, 106-114.

Feitelson, M. A., Arzumanyan, A., Kulathinal, R. J., Blain, S. W., Holcombe, R. F., Mahajna, J., Marino, M., Martinez-Chantar, M. L., Nawroth, R., SanchezGarcia, I., Sharma, D., Saxena, N. K., Singh, N., Vlachostergios, P. J., Guo, S., Honoki, K., Fujii, H., Georgakilas, A. G., Bilsland, A., Amedei, A., Niccolai, E., Amin, A., Ashraf, S. S., Boosani, C. S., Guha, G., Ciriolo, M. R., Aquilano, K., Chen, S., Mohammed, S. I., Azmi, A. S., Bhakta, D., Halicka, D., Keith, W. N., \& Nowsheen, S. (2015). Sustained proliferation in cancer: Mechanisms and novel therapeutic targets. Semin Cancer Biol, 35 Suppl, S25-S54.

Ferreira, C., Van Der Valk, P., Span, S., Jonker, J., Postmus, P., Kruyt, F., \& Giaccone, G. (2001). Assessment of IAP (inhibitor of apoptosis) proteins as predictors of response to chemotherapy in advanced non-small-cell lung cancer patients. Annals of oncology, 12, 799-805.

Ferreira, C. G., van der Valk, P., Span, S. W., Ludwig, I., Smit, E. F., Kruyt, F. A., Pinedo, H. M., van Tinteren, H., \& Giaccone, G. (2001). Expression of X-linked inhibitor of apoptosis as a novel prognostic marker in radically resected non-small cell lung cancer patients. Clinical Cancer Research, 7, 2468-2474.

Fortugno, P., Beltrami, E., Plescia, J., Fontana, J., Pradhan, D., Marchisio, P. C., Sessa, W. C., \& Altieri, D. C. (2003). Regulation of survivin function by Hsp90. Proceedings of the National Academy of Sciences, 100, 13791-13796.

Franklin, M. C., Kadkhodayan, S., Ackerly, H., Alexandru, D., Distefano, M. D., Elliott, L. O., Flygare, J. A., Mausisa, G., Okawa, D. C., \& Ong, D. (2003). Structure and function analysis of peptide antagonists of melanoma inhibitor of apoptosis (ML-IAP). Biochemistry, 42, 8223-8231.

Fulda, S. (2009). Inhibitor of apoptosis proteins in hematological malignancies. Leukemia, 23, 467.

Fulda, S., Wick, W., Weller, M., \& Debatin, K.-M. (2002). Smac agonists sensitize for Apo2L/TRAIL-or anticancer drug-induced apoptosis and induce regression of malignant glioma in vivo. Nature medicine, 8,808

Furuya, M., Tsuji, N., Kobayashi, D., \& Watanabe, N. (2009). Interaction between survivin and aurora-B kinase plays an important role in survivin-mediated upregulation of human telomerase reverse transcriptase expression. Int $J$ Oncol, 34, 1061-1068.

Gaither, A., Porter, D., Yao, Y., Borawski, J., Yang, G., Donovan, J., Sage, D., Slisz, J., Tran, M., Straub, C., Ramsey, T., lourgenko, V., Huang, A., Chen, Y., Schlegel, R., Labow, M., Fawell, S., Sellers, W. R., \& Zawel, L. (2007). A Smac mimetic rescue screen reveals roles for inhibitor of apoptosis proteins in tumor necrosis factor-alpha signaling. Cancer Res, 67, 11493-11498.

Gao, X., Zhang, L., Wei, Y., Yang, Y., Li, J., Wu, H., \& Yin, Y. (2019). Prognostic Value of XIAP Level in Patients with Various Cancers: A Systematic Review and Meta-Analysis. J Cancer, 10, 1528-1537.

Glorian, V., Allegre, J., Berthelet, J., Dumetier, B., Boutanquoi, P. M., Droin, N., Kayaci, C., Cartier, J., Gemble, S., Marcion, G., Gonzalez, D., Boidot, R., Garrido, C., Michaud, O., Solary, E., \& Dubrez, L. (2017). DNA damage and S phase-dependent E2F1 stabilization requires the cIAP1 E3-ubiquitin ligase and is associated with K63-poly-ubiquitination on lysine 161/164 residues. Cell Death Dis, 8, e2816.

Gomez-Roca, C., Even, C., Le Tourneau, C., Rotllan, N. B., Delord, J.-P., Sarini, J., Vergez, S., Teman, S., Hoffmann, C., \& Rochaix, P. (2019). Open-label, nonrandomized, exploratory pre-operative window-of-opportunity trial to investigate the pharmacokinetics and pharmacodynamics of the smac mimetic Debio 1143 in patients with resectable squamous cell carcinoma of the head and neck. In: AACR.

Gradzka, S., Thomas, O. S., Kretz, O., Haimovici, A., Vasilikos, L., Wong, W. W., Hacker, G., \& Gentle, I. E. (2018). Inhibitor of apoptosis proteins are required for effective fusion of autophagosomes with lysosomes. Cell Death Dis, $9,529$.

Gu, C., Wang, Z., Jin, Z., Li, G., Kou, Y., Jia, Z., Yang, J., \& Tian, F. (2017). MicroRNA-212 inhibits the proliferation, migration and invasion of renal cell carcinoma by targeting X-linked inhibitor of apoptosis protein (XIAP). Oncotarget, 8, 92119.

Gully, C. P., Velazquez-Torres, G., Shin, J. H., Fuentes-Mattei, E., Wang, E., Carlock, C., Chen, J., Rothenberg, D., Adams, H. P., Choi, H. H., Guma, S., Phan, L., Chou, P. C., Su, C. H., Zhang, F., Chen, J. S., Yang, T. Y., Yeung, S. C., \& Lee, M. H. (2012). Aurora B kinase phosphorylates and instigates degradation of p53. Proc Natl Acad Sci U S A, 109, E1513-1522. 
Gyrd-Hansen, M., Darding, M., Miasari, M., Santoro, M. M., Zender, L., Xue, W., Tenev, T., da Fonseca, P. C., Zvelebil, M., Bujnicki, J. M., Lowe, S., Silke, J., \& Meier, P. (2008). IAPs contain an evolutionarily conserved ubiquitin-binding domain that regulates NF-kappaB as well as cell survival and oncogenesis. Nat Cell Biol, 10, 1309-1317.

Gyrd-Hansen, M., \& Meier, P. (2010). IAPs: from caspase inhibitors to modulators of NF-kappaB, inflammation and cancer. Nat Rev Cancer, 10, 561-574. Haga, R. B., \& Ridley, A. J. (2016). Rho GTPases: Regulation and roles in cancer cell biology. Small GTPases, 7, 207-221.

Hagenbuchner, J., Kiechl-Kohlendorfer, U., Obexer, P., \& Ausserlechner, M. J. (2016). BIRC5/Survivin as a target for glycolysis inhibition in high-stage neuroblastoma. Oncogene, 35, 2052-2061.

Hagenbuchner, J., Kuznetsov, A. V., Obexer, P., \& Ausserlechner, M. J. (2013). BIRC5/Survivin enhances aerobic glycolysis and drug resistance by altered regulation of the mitochondrial fusion/fission machinery. Oncogene, 32, 4748-4757.

Hanahan, D., \& Weinberg, R. A. (2011). Hallmarks of cancer: the next generation. Cell, 144, 646-674.

Hao, Y., Baker, D., \& Ten Dijke, P. (2019). TGF-beta-Mediated Epithelial-Mesenchymal Transition and Cancer Metastasis. Int J Mol Sci, 20.

Hashimoto, T., \& Shibasaki, F. (2015). Hypoxia-inducible factor as an angiogenic master switch. Front Pediatr, 3, 33.

Hennessy, E. J., Adam, A., Aquila, B. M., Castriotta, L. M., Cook, D., Hattersley, M., Hird, A. W., Huntington, C., Kamhi, V. M., \& Laing, N. M. (2013). Discovery of a novel class of dimeric Smac mimetics as potent IAP antagonists resulting in a clinical candidate for the treatment of cancer (AZD5582). Journal of medicinal chemistry, 56, 9897-9919.

Hess, C. J., Berkhof, J., Denkers, F., Ossenkoppele, G. J., Schouten, J. P., Oudejans, J. J., Waisfisz, Q., \& Schuurhuis, G. J. (2007). Activated Intrinsic Apoptosis Pathway Is a Key Related Prognostic Parameter in Acute Myeloid Leukemia. Journal of Clinical Oncology, 25, 1209-1215.

Hossain, M. M., Banik, N. L., \& Ray, S. K. (2012). Survivin knockdown increased anti-cancer effects of (-)-epigallocatechin-3-gallate in human malignant neuroblastoma SK-N-BE2 and SH-SY5Y cells. Exp Cell Res, 318, 1597-1610.

Huang J, Lyu, H., Wang, J., \& Liu, B. (2015). MicroRNA regulation and therapeutic targeting of survivin in cancer. American journal of cancer research, 5, 20. Huang, J., Yao, W. Y., Zhu, Q., Tu, S. P., Yuan, F., Wang, H. F., Zhang, Y. P., \& Yuan, Y. Z. (2010). XAF1 as a prognostic biomarker and therapeutic target in pancreatic cancer. Cancer Sci, 101, 559-567.

Huang, X., Wu, Z., Mei, Y., \& Wu, M. (2013). XIAP inhibits autophagy via XIAP-Mdm2-p53 signalling. EMBO J, 32, 2204-2216.

Humphreys, L., Espona-Fiedler, M., \& Longley, D. B. (2018). FLIP as a therapeutic target in cancer. FEBS J, 285, 4104-4123.

Hunter, A. M., LaCasse, E. C., \& Korneluk, R. G. (2007). The inhibitors of apoptosis (IAPs) as cancer targets. Apoptosis, 12, 1543-1568.

Hurwitz, H. I., Smith, D. C., Pitot, H. C., Brill, J. M., Chugh, R., Rouits, E., Rubin, J., Strickler, J., Vuagniaux, G., Sorensen, J. M., \& Zanna, C. (2015). Safety, pharmacokinetics, and pharmacodynamic properties of oral DEBIO1143 (AT-406) in patients with advanced cancer: results of a first-in-man study . Cancer Chemother Pharmacol, 75, 851-859.

Imoto, I., Tsuda, H., Hirasawa, A., Miura, M., Sakamoto, M., Hirohashi, S., \& Inazawa, J. (2002). Expression of clAP1, a Target for 11q22 Amplification, Correlates with Resistance of Cervical Cancers to Radiotherapy. Cancer research, 62, 4860-4866.

Imoto, I., Yang, Z.-Q., Pimkhaokham, A., Tsuda, H., Shimada, Y., Imamura, M., Ohki, M., \& Inazawa, J. (2001). Identification of clAP1 as a candidate target gene within an amplicon at 11q22 in esophageal squamous cell carcinomas. Cancer research, 61, 6629-6634.

Imre, G., Larisch, S., \& Rajalingam, K. (2011). Ripoptosome: a novel IAP-regulated cell death-signalling platform. J Mol Cell Biol, 3, 324-326.

Ito, T., Shiraki, K., Sugimoto, K., Yamanaka, T., Fujikawa, K., Ito, M., Takase, K., Moriyama, M., Kawano, H., \& Hayashida, M. (2000). Survivin promotes cell proliferation in human hepatocellular carcinoma. Hepatology, 31, 1080-1085

Jeon, C., Kim, M., Kwak, C., Kim, H. H., \& Ku, J. H. (2013). Prognostic role of survivin in bladder cancer: a systematic review and meta-analysis. PLoS One, 8 , e76719.

Jin, Y., Lu, X., Wang, M., Zhao, X., \& Xue, L. (2019). X-linked inhibitor of apoptosis protein accelerates migration by inducing epithelial-mesenchymal transition through TGF-beta signaling pathway in esophageal cancer cells. Cell Biosci, $9,76$.

Jo, S. J., Park, P.-G., Cha, H.-R., Ahn, S. G., Kim, M. J., Kim, H., Koo, J. S., Jeong, J., Park, J. H., \& Dong, S. M. (2017). Cellular inhibitor of apoptosis protein 2 promotes the epithelial-mesenchymal transition in triple-negative breast cancer cells through activation of the AKT signaling pathway. Oncotarget, 8 , 78781

Kanwar, J. R., Kamalapuram, S. K., \& Kanwar, R. K. (2011). Targeting survivin in cancer: the cell-signalling perspective. Drug Discov Today, 16, 485-494. Kasof, G. M., \& Gomes, B. C. (2001). Livin, a novel inhibitor of apoptosis protein family member. Journal of Biological Chemistry, 276, 3238-3246.

Kawasaki, H., Toyoda, M., Shinohara, H., Okuda, J., Watanabe, I., Yamamoto, T., Tanaka, K., Tenjo, T., \& Tanigawa, N. (2001). Expression of survivin correlates with apoptosis, proliferation, and angiogenesis during human colorectal tumorigenesis. Cancer: Interdisciplinary International Journal of the American Cancer Society, 91, 2026-2032.

Kearney, C. J., Lalaoui, N., Freeman, A. J., Ramsbottom, K. M., Silke, J., \& Oliaro, J. (2017). PD-L1 and IAPs co-operate to protect tumors from cytotoxic lymphocyte-derived TNF. Cell Death Differ, 24, 1705-1716.

Kennedy, S. M., O'Driscoll, L., Purcell, R., Fitz-Simons, N., McDermott, E. W., Hill, A. D., O'Higgins, N. J., Parkinson, M., Linehan, R., \& Clynes, M. (2003) Prognostic importance of survivin in breast cancer. Br $J$ Cancer, 88, 1077-1083

Kim, J., Ahn, S., Ko, Y. G., Boo, Y. C., Chi, S. G., Ni, C. W., Go, Y. M., Jo, H., \& Park, H. (2010). X-linked inhibitor of apoptosis protein controls alpha5-integrinmediated cell adhesion and migration. Am J Physiol Heart Circ Physiol, 299, H300-309. 
Kim, J., Park, J., Choi, S., Chi, S. G., Mowbray, A. L., Jo, H., \& Park, H. (2008). X-linked inhibitor of apoptosis protein is an important regulator of vascular endothelial growth factor-dependent bovine aortic endothelial cell survival. Circ Res, 102, 896-904.

Kipp, R. A., Case, M. A., Wist, A. D., Cresson, C. M., Carrell, M., Griner, E., Wiita, A., Albiniak, P. A., Chai, J., \& Shi, Y. (2002). Molecular targeting of inhibitor of apoptosis proteins based on small molecule mimics of natural binding partners. Biochemistry, 41, 7344-7349.

Kitagawa, M., \& Lee, S. H. (2015). The chromosomal passenger complex (CPC) as a key orchestrator of orderly mitotic exit and cytokinesis. Front Cell Dev Biol, 3,14 .

Kleinschmidt-DeMasters, B., Heinz, D., McCarthy, P. J., Bobak, J. B., Lillehei, K. O., Shroyer, A. L. W., \& Shroyer, K. R. (2003). Survivin in glioblastomas: protein and messenger RNA expression and comparison with telomerase levels. Archives of pathology \& laboratory medicine, 127, 826-833.

Kogo, R., How, C., Chaudary, N., Bruce, J., Shi, W., Hill, R. P., Zahedi, P., Yip, K. W., \& Liu, F.-F. (2015). The microRNA-218 Survivin axis regulates migration, invasion, and lymph node metastasis in cervical cancer. Oncotarget, 6, 1090.

Komander, D., \& Rape, M. (2012). The ubiquitin code. Annu Rev Biochem, 81, 203-229.

Krajewska, M., Kim, H., Kim, C., Kang, H., Welsh, K., Matsuzawa, S.-i., Tsukamoto, M., Thomas, R. G., Assa-Munt, N., \& Piao, Z. (2005). Analysis of apoptosis protein expression in early-stage colorectal cancer suggests opportunities for new prognostic biomarkers. Clinical Cancer Research, 11, 5451-5461.

Krock, B. L., Skuli, N., \& Simon, M. C. (2011). Hypoxia-induced angiogenesis: good and evil. Genes Cancer, 2, 1117-1133.

LaCasse, E. C., Mahoney, D. J., Cheung, H. H., Plenchette, S., Baird, S., \& Korneluk, R. G. (2008). IAP-targeted therapies for cancer. Oncogene, 27, 6252-6275. Lagacé, M., Xuan, J.-Y., Young, S. S., McRoberts, C., Maier, J., Rajcan-Separovic, E., \& Korneluk, R. G. (2001). Genomic organization of the X-linked inhibitor of apoptosis and identification of a novel testis-specific transcript. Genomics, 77, 181-188.

Lam, A. K, Saleh, S, Smith, R. A, \& Ho, Y. H. (2008). Quantitative analysis of survivin in colorectal adenocarcinoma: increased expression and correlation with telomerase activity. Hum Pathol, 39, 1229-1233.

Lee, G.-H., Joo, Y.-E., Koh, Y.-S., Chung, I.-J., Park, Y.-K., Lee, J.-H., Kim, H.-S., Choi, S.-K., Rew, J.-S., \& Park, C.-S. (2006). Expression of survivin in gastric cancer and its relationship with tumor angiogenesis. European journal of gastroenterology \& hepatology, 18, 957-963.

Lee, M.-R., Ji, S.-Y., Mia-Jan, K., \& Cho, M.-Y. (2015). Chemoresistance of CD133+ colon cancer may be related with increased survivin expression. Biochemical and biophysical research communications, 463, 229-234.

Li, F., Yin, X., Luo, X., Li, H. Y., Su, X., Wang, X. Y., Chen, L., Zheng, K., \& Ren, G. S. (2013). Livin promotes progression of breast cancer through induction of epithelial-mesenchymal transition and activation of AKT signaling. Cell Signal, 25, 1413-1422.

Li, J., \& Wu, H. (2006). Expression of survivin in human non-Hodgkin lymphoma and its correlation with proliferation and angiogenesis. Journal of Huazhong University of Science and Technology, 26, 504-507.

Li, S., Pan, B., Li, L., Shi, B., Xie, F., \& He, C. (2019). Prognostic significance of X-linked inhibitor of apoptosis protein in solid tumors: A systematic review and meta-analysis. J Cell Physiol, 234, 18111-18122.

Li, W., Li, B., Giacalone, N. J., Torossian, A., Sun, Y., Niu, K., Lin-Tsai, O., \& Lu, B. (2011). BV6, an IAP antagonist, activates apoptosis and enhances radiosensitization of non-small cell lung carcinoma in vitro. Journal of Thoracic Oncology, 6, 1801-1809.

Li, X., Chen, W., Zeng, W., Wan, C., Duan, S., \& Jiang, S. (2017). microRNA-137 promotes apoptosis in ovarian cancer cells via the regulation of XIAP. Br J Cancer, 116, 66-76.

Li, Y. H., Hu, C. F., Shao, Q., Huang, M. Y., Hou, J. H., Xie, D., Zeng, Y. X., \& Shao, J. Y. (2008). Elevated expressions of survivin and VEGF protein are strong independent predictors of survival in advanced nasopharyngeal carcinoma. J Transl Med, 6, 1

Li, Z., Ren, W., Zeng, Q., Chen, S., Zhang, M., Zhao, Y., Cheng, J., \& Wang, X. (2016). Effects of survivin on angiogenesis in vivo and in vitro. American journal of translational research, 8, 270.

Lin, F., Ghislat, G., Luo, S., Renna, M., Siddiqi, F., \& Rubinsztein, D. C. (2015). XIAP and cIAP1 amplifications induce Beclin 1-dependent autophagy through NFkappaB activation. Hum Mol Genet, 24, 2899-2913.

Listen, P., Roy, N., Tamai, K., Lefebvre, C., Baird, S., Cherton-Horvat, G., Farahani, R., McLean, M., Mackenzie, A., \& Korneluk, R. G. (1996). Suppression of apoptosis in mammalian cells by NAIP and a related family of IAP genes. Nature, 379,349

Liu, F., Sun, Y., Liu, B., Lu, J., Li, H., Zhu, H., Gao, H., Zhou, X., \& Chang, H. (2018). Insulin-like growth factor-1 induces epithelial-mesenchymal transition in hepatocellular carcinoma by activating survivin. Oncol Rep, 40, 952-958.

Liu, J., Zhang, D., Luo, W., Yu, J., Li, J., Yu, Y., Zhang, X., Chen, J., Wu, X. R., \& Huang, C. (2012). E3 ligase activity of XIAP RING domain is required for XIAPmediated cancer cell migration, but not for its RhoGDI binding activity. PLoS One, 7, e35682.

Liu, J., Zhang, D., Luo, W., Yu, Y., Yu, J., Li, J., Zhang, X., Zhang, B., Chen, J., Wu, X. R., Rosas-Acosta, G., \& Huang, C. (2011). X-linked inhibitor of apoptosis protein (XIAP) mediates cancer cell motility via Rho GDP dissociation inhibitor (RhoGDI)-dependent regulation of the cytoskeleton. J Biol Chem, 286, 15630-15640.

Liu, Z., Sun, C., Olejniczak, E. T., Meadows, R. P., Betz, S. F., Oost, T., Herrmann, J., Wu, J. C., \& Fesik, S. W. (2000). Structural basis for binding of Smac/DIABLO to the XIAP BIR3 domain. Nature, 408, 1004

Lopes, R. B., Gangeswaran, R., McNeish, I. A., Wang, Y., \& Lemoine, N. R. (2007). Expression of the IAP protein family is dysregulated in pancreatic cancer cells and is important for resistance to chemotherapy. Int I Cancer, 120, 2344-2352. 
Lu, J., Bai, L., Sun, H., Nikolovska-Coleska, Z., McEachern, D., Qiu, S., Miller, R. S., Yi, H., Shangary, S., \& Sun, Y. (2008). SM-164: a novel, bivalent Smac mimetic that induces apoptosis and tumor regression by concurrent removal of the blockade of CIAP-1/2 and XIAP. Cancer research, 68, 9384-9393.

Lu, M., Lin, S.-C., Huang, Y., Kang, Y. J., Rich, R., Lo, Y.-C., Myszka, D., Han, J., \& Wu, H. (2007). XIAP induces NF-KB activation via the BIR1/TAB1 interaction and BIR1 dimerization. Molecular cell, 26, 689-702.

Lv, X., Li, J., Zhang, C., Hu, T., Li, S., He, S., Yan, H., Tan, Y., Lei, M., Wen, M., \& Zuo, J. (2017). The role of hypoxia-inducible factors in tumor angiogenesis and cell metabolism. Genes Dis, 4, 19-24.

Ma, A., Lin, R., Chan, P. K., Leung, J. C., Chan, L. Y., Meng, A., Verfaillie, C. M., Liang, R., \& Leung, A. Y. (2007). The role of survivin in angiogenesis during zebrafish embryonic development. BMC Dev Biol, 7, 50.

Marivin, A., Berthelet, J., Cartier, J., Paul, C., Gemble, S., Morizot, A., Boireau, W., Saleh, M., Bertoglio, J., Solary, E., \& Dubrez, L. (2014). clAP1 regulates TNFmediated cdc42 activation and filopodia formation. Oncogene, 33, 5534-5545.

Martin, T. A., Ye, L., Sanders, A. J., Lane, J., \& Jiang, W. G. (2013). Cancer invasion and metastasis: molecular and cellular perspective. In Madame Curie Bioscience Database [Internet]: Landes Bioscience.

Murio, A. M., Dohi, T., \& Altieri, D. C. (2010). IAP regulation of metastasis. Cancer Cell, 17, 53-64.

Mehta, A., Hollebecque, A., Foss, F., Lister, J., Mita, M., Wagner-Johnston, N., Dyer, M., You, B., Prica, A., \& Hernandez-Llizaliturri, F. (2019). PRELIMINARY RESULTS OF ASTX660, A NOVEL NON-PEPTIDOMIMETIC CIAP1/2 AND XIAP ANTAGONIST, IN RELAPSED/REFRACTORY PERIPHERAL T-CELL LYMPHOMA AND CUTANEOUS T CELL LYMPHOMA: PS1073. HemaSphere, 3, 486

Meng, L., Fuhao, Z., Xiaoming, Z., Yuxiu, Z., Zhaojun, D., Bingcheng, L., Meiling, X., \& Shuyan, S. (2018). Survivin is critically involved in VEGFR2 signalingmediated esophageal cancer cell survival. Biomed Pharmacother, 107, 139-145.

Micheau, O., \& Tschopp, J. (2003). Induction of TNF Receptor I-Mediated Apoptosis via Two Sequential Signaling Complexes. Cell, 114, 181-190.

Ming, L., Tao, S., Yin, Z.-f., \& Na, Y.-q. (2007). XIAP as a prognostic marker of early recurrence of nonmuscular invasive bladder cancer. Chinese medical journal, 120, 469-473.

Mizutani, Y., Nakanishi, H., Li, Y. N., Matsubara, H., Yamamoto, K., Sato, N., Shiraishi, T., Nakamura, T., Mikami, K., \& Okihara, K. (2007). Overexpression of XIAP expression in renal cell carcinoma predicts a worse prognosis. International journal of oncology, 30, 919-925.

Muz, B., de la Puente, P., Azab, F., \& Azab, A. K. (2015). The role of hypoxia in cancer progression, angiogenesis, metastasis, and resistance to therapy Hypoxia (Auckl), 3, 83-92

Nachmias, B., Mizrahi, S., Elmalech, M., Lazar, I., Ashhab, Y., Gazit, R., Markel, G., Ben-Yehuda, D., \& Mandelboim, O. (2007). Manipulation of NK cytotoxicity by the IAP family member Livin. Eur J Immunol, 37, 3467-3476.

Ni, T., Li, W., \& Zou, F. (2005). The ubiquitin ligase ability of IAPs regulates apoptosis. IUBMB Life, 57, 779-785.

Noonan, A. M., Bunch, K. P., Chen, J. Q., Herrmann, M. A., Lee, J. M., Kohn, E. C., O'Sullivan, C. C., Jordan, E., Houston, N., \& Takebe, N. (2016). Pharmacodynamic markers and clinical results from the phase 2 study of the SMAC mimetic birinapant in women with relapsed platinum-resistant orrefractory epithelial ovarian cancer. Cancer, 122, 588-597.

O'Connor, D. S., Grossman, D., Plescia, J., Li, F., Zhang, H., Villa, A., Tognin, S., Marchisio, P. C., \& Altieri, D. C. (2000). Regulation of apoptosis at cell division by p34cdc2 phosphorylation of survivin. Proceedings of the National Academy of Sciences, 97, 13103-13107.

O'Connor, D. S., Schechner, J. S., Adida, C., Mesri, M., Rothermel, A. L., Li, F., Nath, A. K., Pober, J. S., \& Altieri, D. C. (2000). Control of apoptosis during angiogenesis by survivin expression in endothelial cells. The American Journal of Pathology, 156, 393-398.

Oberoi-Khanuja, T. K., Karreman, C., Larisch, S., Rapp, U. R., \& Rajalingam, K. (2012). Role of melanoma inhibitor of apoptosis (ML-IAP) protein, a member of the baculoviral IAP repeat (BIR) domain family, in the regulation of C-RAF kinase and cell migration. J Biol Chem, 287, 28445-28455.

Oberoi-Khanuja, T. K., \& Rajalingam, K. (2012). IAPs as E3 ligases of Rac1: shaping the move. Small GTPases, 3, 131-136.

Oberoi, T. K., Dogan, T., Hocking, J. C., Scholz, R. P., Mooz, J., Anderson, C. L., Karreman, C., Meyer zu Heringdorf, D., Schmidt, G., Ruonala, M., Namikawa, K, Harms, G. S., Carpy, A., Macek, B., Koster, R. W., \& Rajalingam, K. (2012). IAPs regulate the plasticity of cell migration by directly targeting Rac1 for degradation. EMBO J, 31, 14-28.

Detjen, K. A., \& Duckett, C. S. (2011). Identifying the trigger of c-IAPs: structural and functional characterization of CARD-mediated modulation of ubiquitin ligase activity. Mol Cell, 42, 553-554.

Oost, T. K., Sun, C., Armstrong, R. C., Al-Assaad, A.-S., Betz, S. F., Deckwerth, T. L., Ding, H., Elmore, S. W., Meadows, R. P., \& Olejniczak, E. T. (2004). Discovery of potent antagonists of the antiapoptotic protein XIAP for the treatment of cancer. Journal of medicinal chemistry, 47, 4417-4426.

Park, M. H., \& Hong, J. T. (2016). Roles of NF-KB in cancer and inflammatory diseases and their therapeutic approaches. Cells, 5, 15.

Parton, M., Bardia, A., Kummel, S., Estevez, L. G., Huang, C.-S., Castan, J. C., Ruiz Borrego, M., Telli, M. L., Lluch, A., \& Lopez, R. (2015). A phase II, open-label, neoadjuvant, randomized study of LCL161 with paclitaxel in patients with triple-negative breast cancer (TNBC). In: American Society of Clinical Oncology.

Pei, G., Lan, Y., Chen, D., Ji, L., \& Hua, Z.-c. (2017). FAK regulates E-cadherin expression via p-SrcY416/p-ERK1/2/p-Stat3Y705 and PPARY/miR-125b/Stat3 signaling pathway in B16F10 melanoma cells. Oncotarget, 8, 13898 . 
Pemmaraju, N., Carter, B. Z., Kantarjian, H. M., Cortes, J. E., Kadia, T. M., Garcia-Manero, G., DiNardo, C. D., Bose, P., Daver, N. G., \& Konopleva, M. Y. (2018) LCL161, an oral Smac mimetic/IAP antagonist for patients with myelofibrosis (MF): Novel translational findings among long-term responders in a phase 2 clinical trial. In: Am Soc Hematology.

Peng, Y., \& Croce, C. M. (2016). The role of MicroRNAs in human cancer. Signal Transduct Target Ther, 1, 15004

Peng, Y., Sun, H., Lu, J., Liu, L., Cai, Q., Shen, R., Yang, C.-Y., Yi, H., \& Wang, S. (2011). Bivalent Smac mimetics with a diazabicyclic core as highly potent antagonists of XIAP and cIAP1/2 and novel anticancer agents. Journal of medicinal chemistry, 55, 106-114.

Perez, H. L., Chaudhry, C., Emanuel, S. L., Fanslau, C., Fargnoli, J., Gan, J., Kim, K. S., Lei, M., Naglich, J. G., \& Traeger, S. C. (2015). Discovery of potent heterodimeric antagonists of inhibitor of apoptosis proteins (IAPs) with sustained antitumor activity. Journal of medicinal chemistry, 58, 1556-1562.

Perkins, N. D. (2007). Integrating cell-signalling pathways with NF-kappaB and IKK function. Nat Rev Mol Cell Biol, 8, 49-62.

Petersen, S. L., Wang, L., Yalcin-Chin, A., Li, L., Peyton, M., Minna, J., Harran, P., \& Wang, X. (2007). Autocrine TNFalpha signaling renders human cancer cells susceptible to Smac-mimetic-induced apoptosis. Cancer Cell, 12, 445-456.

Pluta, A., Wierzbowska, A., Cebula-Obrzut, B., Pluta, P., Stępka, K., Szmigielska-Kapłon, A., Grzybowska-Izydorczyk, O., Czemerska, M., Smolewski, P., \& Wrzesien-Kus, A. (2015). Prognostic value of inhibitor of apoptosis protein family expression in patients with acute myeloid leukemia. Leukemia \& lymphoma, 56, 2529-2535.

Pluta, P., Jeziorski, A., Cebula-Obrzut, A. P., Wierzbowska, A., Piekarski, J., \& Smolewski, P. (2015). Expression of IAP family proteins and its clinical importance in breast cancer patients. Neoplasma, 62, 666-673.

Pötsch, I., Ebner, P., Deszcz, L., Bachtrog, I., Stephani, M., Díaz, C. G., Dagdas, Y., \& Ikeda, F. (2018). The anti-apoptosis ubiquitin E3 ligase XIAP promotes autophagosome-lysosome fusion during autophagy. bioRxiv, 291294

Ramp, U., Krieg, T., Caliskan, E., Mahotka, C., Ebert, T., Willers, R., Gabbert, H. E., \& Gerharz, C. D. (2004). XIAP expression is an independent prognostic marker in clear-cell renal carcinomas. Human pathology, 35, 1022-1028.

Ren, Y., Han, X., Yu, K., Sun, S., Zhen, L., Li, Z., \& Wang, S. (2014). microRNA-200c downregulates XIAP expression to suppress proliferation and promote apoptosis of triple-negative breast cancer cells. Mol Med Rep, 10, 315-321.

Riedl, S. J., Renatus, M., Schwarzenbacher, R., Zhou, Q., Sun, C., Fesik, S. W., Liddington, R. C., \& Salvesen, G. S. (2001). Structural basis for the inhibition of caspase-3 by XIAP. Cell, 104, 791-800.

Riley, J. S., Malik, A., Holohan, C., \& Longley, D. B. (2015). DED or alive: assembly and regulation of the death effector domain complexes. Cell Death Dis, 6 , e1866.

Rivadeneira, D. B., Caino, M. C., Seo, J. H., Angelin, A., Wallace, D. C., Languino, L. R., \& Altieri, D. C. (2015). Survivin promotes oxidative phosphorylation, subcellular mitochondrial repositioning, and tumor cell invasion. Sci. Signal., 8, ra80-ra80.

Rosebeck, S., Madden, L., Jin, X., Gu, S., Apel, I. J., Appert, A., Hamoudi, R. A., Noels, H., Sagaert, X., \& Van Loo, P. (2011). Cleavage of NIK by the API2-MALT1 fusion oncoprotein leads to noncanonical NF-KB activation. Science, 331, 468-472.

Rothe, M., Pan, M.-G., Henzel, W. J., Ayres, T. M., \& Goeddel, D. V. (1995). The TNFR2-TRAF signaling complex contains two novel proteins related to baculoviral inhibitor of apoptosis proteins. Cell, 83, 1243-1252.

Roy, N., Mahadevan, M. S., McLean, M., Shutter, G., Yaraghi, Z., Farahani, R., Baird, S., Besner-Johnston, A., Lefebvre, C., Kang, X., Salih, M., Aubry, H., Tamai, K., Guan, X., loannou, P., Crawford, T. O., de Jong, P. J., Surh, L., Ikeda, J.-E., Korneluk, R. G., \& MacKenzie, A. (1995). The gene for neuronal apoptosis inhibitory protein is partially deleted in individuals with spinal muscular atrophy. Cell, 80, 167-178.

Ruchaud, S., Carmena, M., \& Earnshaw, W. C. (2007a). The chromosomal passenger complex: one for all and all for one. Cell, 131, 230-231.

Ruchaud, S., Carmena, M., \& Earnshaw, W. C. (2007b). Chromosomal passengers: conducting cell division. Nat Rev Mol Cell Biol, 8, 798-812.

Safa, A. R. (2016). Resistance to Cell Death and Its Modulation in Cancer Stem Cells. Crit Rev Oncog, 21, 203-219.

Safa, A. R. (2019). Resistance to drugs and cell death in cancer stem cells

(CSCs). Journal of Translational Science, 5, 1-10.

Samuel, T., Okada, K., Hyer, M., Welsh, K., Zapata, J. M., \& Reed, J. C. (2005). cIAP1 Localizes to the nuclear compartment and modulates the cell cycle. Cancer research, 65, 210-218.

Samuel, T., Welsh, K., Lober, T., Togo, S. H., Zapata, J. M., \& Reed, J. C. (2006). Distinct BIR domains of cIAP1 mediate binding to and ubiquitination of tumor necrosis factor receptor-associated factor 2 and second mitochondrial activator of caspases. J Biol Chem, 281, 1080-1090.

Sasai, K., Treekitkarnmongkol, W., Kai, K., Katayama, H., \& Sen, S. (2016). Functional Significance of Aurora Kinases-p53 Protein Family Interactions in Cancer. Front Oncol, 6, 247.

Satyanarayana, A., \& Kaldis, P. (2009). Mammalian cell-cycle regulation: several Cdks, numerous cyclins and diverse compensatory mechanisms. Oncogene $28,2925$.

Schilder, R. J., Albertella, M., Strauss, J. F., Sydvander, M., Le, D. T., Norin, S., Mita, M. M., Boström, E., Fu, S., \& Basse, L. (2019). Determination of the recommended phase II dose of birinapant in combination with pembrolizumab: Results from the dose-escalation phase of BPT-201. In: American Society of Clinical Oncology.

Schile, A. J., Garcia-Fernandez, M., \& Steller, H. (2008). Regulation of apoptosis by XIAP ubiquitin-ligase activity. Genes Dev, 22, 2256-2266. 
Schmollinger, J., \& Dranoff, G. (2004). Targeting melanoma inhibitor of apoptosis protein with cancer immunotherapy. Apoptosis, 9, 309-313.

Schmollinger, J. C., Vonderheide, R. H., Hoar, K. M., Maecker, B., Schultze, J. L., Hodi, F. S., Soiffer, R. J., Jung, K., Kuroda, M. J., \& Letvin, N. L. (2003). Melanoma inhibitor of apoptosis protein (ML-IAP) is a target for immune-mediated tumor destruction. Proceedings of the National Academy of Sciences, 100, 3398-3403.

Senzer, N. N., LoRusso, P., Martin, L. P., Schilder, R. J., Amaravadi, R. K., Papadopoulos, K. P., Segota, Z. E., Weng, D. E., Graham, M., \& Adjei, A. A. (2013) Phase II clinical activity and tolerability of the SMAC-mimetic birinapant (TL32711) plus irinotecan in irinotecan-relapsed/refractory metastatic colorectal cancer. In: American Society of Clinical Oncology.

Shen, J., Sun, H., Meng, Q., Yin, Q., Zhang, Z., Yu, H., \& Li, Y. (2014). Simultaneous inhibition of tumor growth and angiogenesis for resistant hepatocellular carcinoma by co-delivery of sorafenib and survivin small hairpin RNA. Mol Pharm, 11, 3342-3351.

Sheng R., Sun, H., Liu, L., Lu, J., McEachern, D., Wang, G., Wen, J., Min, P., Du, Z., \& Lu, H. (2013). A potent bivalent Smac mimetic (SM-1200) achieving rapid complete, and durable tumor regression in mice. Journal of medicinal chemistry, 56, 3969-3979.

Sherr, C. J., Beach, D., \& Shapiro, G. I. (2016). Targeting CDK4 and CDK6: From Discovery to Therapy. Cancer Discov, 6, 353-367.

Shi, Y. (2002). A conserved tetrapeptide motif: potentiating apoptosis through IAP-binding. In: Nature Publishing Group.

Shibata, T., Mahotka, C., Wethkamp, N., Heikaus, S., Gabbert, H. E., \& Ramp, U. (2007). Disturbed expression of the apoptosis regulators XIAP, XAF1, and Smac/DIABLO in gastric adenocarcinomas. Diagnostic Molecular Pathology, 16, 1-8.

Siddharth, S., Das, S., Nayak, A., \& Kundu, C. N. (2016). SURVIVIN as a marker for quiescent-breast cancer stem cells-An intermediate, adherent, pre-requisite phase of breast cancer metastasis. Clin Exp Metastasis, 33, 661-675.

\& Meier, P. (2013). Inhibitor of apoptosis (IAP) proteins-modulators of cell death and inflammation. Cold Spring Harb Perspect Biol, 5.

Souberan, A., Cappai, J., Chocry, M., Nuccio, C., Raujol, J., Colin, C., Lafitte, D., Kovacic, H., Quillien, V., Baeza-Kallee, N., Rougon, G., Figarella-Branger, D., \& Tchoghandjian, A. (2019). Inhibitor of Apoptosis Proteins Determines Glioblastoma Stem-Like Cell Fate in an Oxygen-Dependent Manner. Stem Cells, $37,731-742$.

Srinivasula, S. M., \& Ashwell, J. D. (2008). IAPs: what's in a name? Mol Cell, 30, 123-135.

Steller, H. (1995). Mechanisms and genes of cellular suicide. Science, 267, 1445-1449.

Sumi, H., Yabuki, M., Iwai, K., Morimoto, M., Hibino, R., Inazuka, M., Hashimoto, K., Kosugi, Y., Aoyama, K., Yamamoto, S., Yoshimatsu, M., Yamasaki, H., Tozawa, R., Ishikawa, T., \& Yoshida, S. (2013). Antitumor activity and pharmacodynamic biomarkers of a novel and orally available small-molecule antagonist of inhibitor of apoptosis proteins. Mol Cancer Ther, 12, 230-240.

Sun, C., Cai, M., Gunasekera, A. H., Meadows, R. P., Wang, H., Chen, J., Zhang, H., Wu, W., Xu, N., \& Ng, S.-C. (1999). NMR structure and mutagenesis of the inhibitor-of-apoptosis protein XIAP. Nature, 401, 818.

Sun, H., Nikolovska-Coleska, Z., Lu, J., Meagher, J. L., Yang, C.-Y., Qiu, S., Tomita, Y., Ueda, Y., Jiang, S., \& Krajewski, K. (2007). Design, synthesis, and characterization of a potent, nonpeptide, cell-permeable, bivalent Smac mimetic that concurrently targets both the BIR2 and BIR3 domains in XIAP. Journal of the American Chemical Society, 129, 15279-15294.

Sun, H., Nikolovska-Coleska, Z., Yang, C.-Y., Xu, L., Liu, M., Tomita, Y., Pan, H., Yoshioka, Y., Krajewski, K., \& Roller, P. P. (2004). Structure-based design of potent, conformationally constrained Smac mimetics. Journal of the American Chemical Society, 126, 16686-16687.

Sun, H., Nikolovska-Coleska, Z., Yang, C.-Y., Xu, L., Tomita, Y., Krajewski, K., Roller, P. P., \& Wang, S. (2004). Structure-based design, synthesis, and evaluation of conformationally constrained mimetics of the second mitochondria-derived activator of caspase that target the $X$-linked inhibitor of apoptosis protein/caspase-9 interaction site. Journal of medicinal chemistry, 47, 4147-4150.

Sun, S. C. (2011). Non-canonical NF-kappaB signaling pathway. Cell Res, 21, 71-85.

Sun, S. C. (2017). The non-canonical NF-kappaB pathway in immunity and inflammation. Nat Rev Immunol $17,545-558$

Sun, X. P., Dong, X., Lin, L., Jiang, X., Wei, Z., Zhai, B., Sun, B., Zhang, Q., Wang, X., Jiang, H., Krissansen, G. W., Qiao, H., \& Sun, X. (2014). Up-regulation of survivin by AKT and hypoxia-inducible factor 1alpha contributes to cisplatin resistance in gastric cancer. FEBS J, 281, 115-128.

Sun, Y. W., Xuan, Q., Shu, Q. A., Wu, S. S., Chen, H., Xiao, J., Xiang, P., Zhu, Y. P., Wang, F. L., \& Zhao, S. T. (2013). Correlation of tumor relapse and elevated expression of survivin and vascular endothelial growth factor in superficial bladder transitional cell carcinoma. Genet Mol Res, 12, 1045-1053.

Suzuki, A., Hayashida, M., Ito, T., Kawano, H., Nakano, T., Miura, M., Akahane, K., \& Shiraki, K. (2000). Survivin initiates cell cycle entry by the competitive interaction with Cdk4/p16 INK4a and Cdk2/cyclin E complex activation. Oncogene, 19, 3225.

Tamm, I., Kornblau, S. M., Segall, H., Krajewski, S., Welsh, K., Kitada, S., Scudiero, D. A., Tudor, G., Qui, Y. H., \& Monks, A. (2000). Expression and prognostic significance of IAP-family genes in human cancers and myeloid leukemias. Clinical Cancer Research, 6, 1796-1803.

Tamm, I., Richter, S., Scholz, F., Schmelz, K., Oltersdorf, D., Karawajew, L., Schoch, C., Haferlach, T., Ludwig, W.-D., \& Wuchter, C. (2004). XIAP expression correlates with monocytic differentiation in adult de novo AML: impact on prognosis. The Hematology Journal, 5, 489-495.

Tchoghandjian, A., Jennewein, C., Eckhardt, I., Momma, S., Figarella-Branger, D., \& Fulda, S. (2014). Smac mimetic promotes glioblastoma cancer stem-like cell differentiation by activating NF-K B. Cell Death \& Differentiation, 21, 735-747.

Tenev, T., Bianchi, K., Darding, M., Broemer, M., Langlais, C., Wallberg, F., Zachariou, A., Lopez, J., MacFarlane, M., Cain, K., \& Meier, P. (2011). The Ripoptosome, a signaling platform that assembles in response to genotoxic stress and loss of IAPs. Mol Cell, 43, 432-448. 
Tran, J., Rak, J., Sheehan, C., Saibil, S. D., LaCasse, E., Korneluk, R. G., \& Kerbel, R. S. (1999). Marked induction of the IAP family antiapoptotic proteins survivin and XIAP by VEGF in vascular endothelial cells. Biochemical and biophysical research communications, 264, 781-788.

Tsuchiya, Y., Nakabayashi, O., \& Nakano, H. (2015). FLIP the Switch: Regulation of Apoptosis and Necroptosis by cFLIP. International journal of molecular sciences, 16, 30321-30341.

Tu, S. P., Jiang, X. H., Lin, M. C., Cui, J. T., Yang, Y., Lum, C. T., Zou, B., Zhu, Y. B., Jiang, S. H., \& Wong, W. M. (2003). Suppression of survivin expression inhibits in vivo tumorigenicity and angiogenesis in gastric cancer. Cancer research, 63, 7724-7732.

Vader, G., Kauw, J. J., Medema, R. H., \& Lens, S. M. (2006). Survivin mediates targeting of the chromosomal passenger complex to the centromere and midbody. EMBO Rep, 7, 85-92.

Van Houdt, W. J., Emmink, B. L., Pham, T. V., Piersma, S. R., Verheem, A, Vries, R. G., Fratantoni, S. A. Pronk, A., Clevers, H., Borel Rinkes, I. H. M., Jimenez, C. R., \& Kranenburg, O. (2011). Comparative Proteomics of Colon Cancer Stem Cells and Differentiated Tumor Cells Identifies BIRC6 as a Potential Therapeutic Target. Molecular \& Cellular Proteomics, 10.

Vaux, D. L., \& Silke J. (2005). IAPs, RINGs and ubiquitylation. Nat Rev Mol Cell Biol, 6, 287-297.

Verhagen, A. M., Coulson, E. J., \& Vaux, D. L. (2001). Inhibitor of apoptosis proteins and their relatives: IAPs and other BIRPs. Genome biology, 2, reviews3009. 3001.

Verhagen, A. M., Ekert, P. G., Pakusch, M., Silke, J., Connolly, L. M., Reid, G. E., Moritz, R. L., Simpson, R. J., \& Vaux, D. L. (2000). Identification of DIABLO, a mammalian protein that promotes apoptosis by binding to and antagonizing IAP proteins. Cell, 102, 43-53.

Vince, J. E., Wong, W. W., Khan, N., Feltham, R., Chau, D., Ahmed, A. U., Benetatos, C. A., Chunduru, S. K., Condon, S. M., McKinlay, M., Brink, R., Leverkus, M., Tergaonkar, V., Schneider, P., Callus, B. A., Koentgen, F., Vaux, D. L., \& Silke, J. (2007). IAP antagonists target cIAP1 to induce TNFalpha-dependent apoptosis. Cell, 131, 682-693.

Vucic, D. Deshayes, K, Ackerly, H., Pisabarro, M. T., Kadkhodayan, S., Fairbrother, W. J., \& Dixit, V. M. (2002). SMAC negatively regulates the anti-apoptotic activity of melanoma inhibitor of apoptosis (ML-IAP). Journal of Biological Chemistry, 277, 12275-12279.

Wang, C., Zheng, X., Shen, C., \& Shi, Y. (2012). MicroRNA-203 suppresses cell proliferation and migration by targeting BIRC5 and LASP1 in human triplenegative breast cancer cells. Journal of experimental \& clinical cancer research, $31,58$.

Wang, L., Du, F., \& Wang, X. (2008). TNF-alpha induces two distinct caspase-8 activation pathways. Cell, 133, 693-703.

Wang, L., Zheng, H., Tang, W., Li, G., \& An, W. (2009). Effects of livin gene silencing by siRNA on apoptosis and cell cycle of human malignant melanoma A375 cells. Tumor, 29, 345-349.

Wang, P., Zhen, H., Zhang, J., Zhang, W., Zhang, R., Cheng, X., Guo, G., Mao, X., Wang, J., \& Zhang, X. (2012). Survivin promotes glioma angiogenesis through vascular endothelial growth factor and basic fibroblast growth factor in vitro and in vivo. Mol Carcinog, 51, 586-595.

Wang, R., Lin, F., Wang, X., Gao, P., Dong, K., Zou, A. M., Cheng, S. Y., Wei, S. H., \& Zhang, H. Z. (2008). Silencing Livin gene expression to inhibit proliferation and enhance chemosensitivity in tumor cells. Cancer Gene Ther, 15, 402-412.

Wellenhofer, A., \& Brustmann, H. (2012). Expression of human telomerase reverse transcriptase in vulvar intraepithelial neoplasia and squamous cell carcinoma: an immunohistochemical study with survivin and p53. Arch Pathol Lab Med, 136, 1359-1365.

Wilson, T., Johnston, P., \& Longley, D. (2009). Anti-apoptotic mechanisms of drug resistance in cancer. Current cancer drug targets, 9, 307-319.

Wu, G., Chai, J., Suber, T. L., Wu, J.-W., Du, C., Wang, X., \& Shi, Y. (2000). Structural basis of IAP recognition by Smac/DIABLO. Nature, 408, 1008

Wu, Y., \& Zhou, B. P. (2010). TNF-alpha/NF-kappaB/Snail pathway in cancer cell migration and invasion. Br J Cancer, 102, 639-644.

Würl, P., Kappler, M., Meye, A., Bartel, F., Köhler, T., Lautenschläger, C., Bache, M., Schmidt, H., \& Taubert, H. (2002). Co-expression of survivin and TERT and risk of tumour-related death in patients with soft-tissue sarcoma. The Lancet, 359, 943-945.

Xia, L., Tan, S., Zhou, Y., Lin, J., Wang, H., Oyang, L., Tian, Y., Liu, L., Su, M., \& Wang, H. (2018). Role of the NFKB-signaling pathway in cancer. OncoTargets and therapy, 11, 2063.

Xiang, G., Wen, X., Wang, H., Chen, K., \& Liu, H. (2009). Expression of X-linked inhibitor of apoptosis protein in human colorectal cancer and its correlation with prognosis. J Surg Oncol, 100, 708-712.

Xie, Y., Tobin, L. A., Camps, J., Wangsa, D., Yang, J., Rao, M., Witasp, E., Awad, K. S., Yoo, N., Ried, T., \& Kwong, K. F. (2013). MicroRNA-24 regulates XIAP to reduce the apoptosis threshold in cancer cells. Oncogene, 32, 2442-2451.

Xu, G. C., Zhang, P., Leng, F., Pan, L., Li, Z. Y., Yu, D. D., Shan, Y., Yuan, Q. Z., Wen, Y., Mu, B., Shi, H. S., Chen, X., \& Wang, C. T. (2012). Inhibition of lymphatic metastases by a survivin dominant-negative mutant. Oncol Res, 20, 579-587.

Xu, L., Zhu, J., Hu, X., Zhu, H., Kim, H. T., LaBaer, J., Goldberg, A., \& Yuan, J. (2007). c-IAP1 cooperates with Myc by acting as a ubiquitin ligase for Mad1. Mo Cell, 28, 914-922.

Yadav, L., Puri, N., Rastogi, V., Satpute, P., \& Sharma, V. (2015). Tumour Angiogenesis and Angiogenic Inhibitors: A Review. J Clin Diagn Res, 9, XE01-XE05. Yang, L., Zhang, L., Lu, L., \& Wang, Y. (2020). miR-214-3p Regulates Multi-Drug Resistance and Apoptosis in Retinoblastoma Cells by Targeting ABCB1 and XIAP. Onco Targets Ther, 13, 803-811.

Ye, L., Li, S., Ye, D., Yang, D., Yue, F., Guo, Y., Chen, X., Chen, F., Zhang, J., \& Song, X. (2013). Livin expression may be regulated by miR-198 in human prostate cancer cell lines. Eur J Cancer, 49, 734-740. 
Ye, L., Song, X., Li, S., Yang, D., Zhang, J., Che, X., Chen, X., Wang, J., \& Zhang, Z. (2011). Livin-alpha promotes cell proliferation by regulating G1-S cell cycle transition in prostate cancer. Prostate, $71,42-51$.

Yi, X. P., Han, T., Li, Y. X., Long, X. Y., \& Li, W. Z. (2015). Simultaneous silencing of XIAP and survivin causes partial mesenchymal-epithelial transition of human pancreatic cancer cells via the PTEN/PI3K/Akt pathway. Mol Med Rep, 12, 601-608.

Yu, C.-J., Ou, J.-H., Wang, M.-L., Jialielihan, N., \& Liu, Y.-H. (2015). Elevated survivin mediated multidrug resistance and reduced apoptosis in breast cancer stem cells. J BUON, 20, 1287-1294.

Yuan, J., Yang, B. M., Zhong, Z. H., Shats, I., Milyavsky, M., Rotter, V., Lock, R. B., Reddel, R. R., \& MacKenzie, K. L. (2009). Upregulation of survivin during immortalization of nontransformed human fibroblasts transduced with telomerase reverse transcriptase. Oncogene, 28, 2678-2689.

Yun, C. W, \& Lee, S. H. (2018). The Roles of Autophagy in Cancer. Int J Mol Sci, 19.

Zarnegar, B. J, Wang Y, Mahoney, D. J., Dempsey, P. W., Cheung, H. H., He, J, Shiba, T., Yang, X., Yeh, W. C., Mak, T. W., Korneluk, R. G., \& Cheng, G. (2008). Noncanonical NF-kappaB activation requires coordinated assembly of a regulatory complex of the adaptors cIAP1, cIAP2, TRAF2 and TRAF3 and the kinase NIK. Nat Immunol, 9, 1371-1378.

Zender, L., Spector, M. S., Xue, W., Flemming, P., Cordon-Cardo, C., Silke, J., Fan, S.-T., Luk, J. M., Wigler, M., \& Hannon, G. J. (2006). Identification and validation of oncogenes in liver cancer using an integrative oncogenomic approach. Cell, 125, 1253-1267.

Zhang, B., Nikolovska-Coleska, Z., Zhang, Y., Bai, L., Qiu, S., Yang, C.-Y., Sun, H., Wang, S., \& Wu, Y. (2008). Design, synthesis, and evaluation of tricyclic, conformationally constrained small-molecule mimetics of second mitochondria-derived activator of caspases. Journal of medicinal chemistry, 51, $7352-7355$.

Zhang, H. Y., Meng, X., Du, Z. X., Fang, C. Q., Liu, G. L., Wang, H. Q., \& Deng, W. W. (2009). Significance of survivin, caspase-3, and VEGF expression in thyroid carcinoma. Clin Exp Med, 9, 207-213.

Zhang, Y., Zhu, J., Tang, Y., Li, F., Zhou, H., Peng, B., Zhou, C., \& Fu, R. (2011). X-linked inhibitor of apoptosis positive nuclear labeling: a new independent prognostic biomarker of breast invasive ductal carcinoma. Diagn Pathol, 6, 49.

Zhen, H. N., Zhang, X., Hu, P. Z., Yang, T. T., Fei, Z., Zhang, J. N., Fu, L. A., He, X. S., Ma, F. C., \& Wang, X. L. (2005). Survivin expression and its relation with proliferation, apoptosis, and angiogenesis in brain gliomas. Cancer, 104, 2775-2783.

Zinngrebe, J., Schlichtig, F., Kraus, J. M., Meyer, M., Boldrin, E., Kestler, H. A., Meyer, L. H., Fischer-Posovszky, P., \& Debatin, K. M. (2020). Biomarker profile for prediction of response to SMAC mimetic monotherapy in pediatric precursor B-cell acute lymphoblastic leukemia. Int J Cancer, 146, 3219-3231.

Zobel, K., Wang, L., Varfolomeev, E., Franklin, M. C., Elliott, L. O., Wallweber, H. J., Okawa, D. C., Flygare, J. A., Vucic, D., \& Fairbrother, W. J. (2006). Design synthesis, and biological activity of a potent Smac mimetic that sensitizes cancer cells to apoptosis by antagonizing IAPs. ACS chemical biology, 1, 525533. 